\title{
High mountain lakes of the Central Range (Iberian Peninsula): Regional limnology \& environmental changes
}

\author{
Manuel Toro ${ }^{1,2}$, Ignacio Granados ${ }^{1,3}$, Santiago Robles ${ }^{1,4}$, Carlos Montes ${ }^{1}$ \\ ${ }^{1}$ Departamento Interuniversitario de Ecología. Universidad Autónoma de Madrid. Campus de Cantoblanco. \\ 28049 Madrid. Spain. \\ ${ }^{2}$ Centro de Estudios Hidrográficos (CEDEX). Paseo Bajo Virgen del Puerto, 3. 28005 Madrid. Spain. \\ 3 Parque Natural de Peñalara. Centro de Gestión Puente del Perdón. Cta. M-604, Km. 27,6. 28740 \\ Rascafría. Spain. \\ 4 CIMERA Estudios Aplicados, S.L. Parque Científico de Madrid. Pol. Indust. Zona Oeste. 28760 Tres \\ Cantos. Spain. \\ Corresponding author: manuel.toro@cedex.es
}

\begin{abstract}
High mountain lake ecosystems in the Iberian Peninsula, being more than 1700 water bodies, are represented mainly by small or medium size lakes ( $75 \%$ with a surface less than $0.5 \mathrm{Ha}$.). The knowledge of their regional limnology in Spain is yet uneven and insufficient, as well as their ecological status and sensitivity to human activity impacts. This work describes the major limnological characteristics and functioning of high mountain lakes in the Spanish Central Range, and their relationships with regional environmental variables and existing human pressures. Some hydrological processes (turnover rate), thermal properties (ice-cover dynamics) or hydrochemical parameters (conductivity) are discussed in more detail in those lakes with long term monitoring data. The composition of planktonic and benthic communities responds to both human pressures and biogeographical or environmental aspects. The effects produced by tourism, cattle, lake damming, wastewater inflow, watershed erosion, introduction of the brook trout, or environmental warming, are studied in some lakes. Implemented management and restoration measures to reduce environmental impacts are described and evaluated.
\end{abstract}

Key words: High mountain lakes, environmental change, human impacts, paleolimnology, lake restoration, regional limnology, Spanish Central Range.

\section{RESUMEN}

Los ecosistemas acuáticos leníticos de alta montaña de la Península Ibérica, con un número superior a 1700 masas de agua, se hallan representados en su mayor parte por lagos de pequeño o mediano tamaño (el $75 \%$ presenta una superficie inferior a $0.5 \mathrm{Ha}$.). El conocimiento limnológico regional de estos sistemas es aún muy limitado e irregular en España, así como su estado de conservación y su sensibilidad ante los posibles impactos producidos por las actividades humanas. Este trabajo describe los principales aspectos limnológicos y el funcionamiento de las lagunas de alta montaña del Sistema Central en territorio español, en relación con las variables ambientales regionales y con las principales presiones humanas a las que se hallan sometidas. Algunos procesos hidrológicos (tasa de renovación), térmicos (cubierta de hielo) o hidroquímicos (mineralización) son abordados con mayor detalle en aquellas lagunas con un seguimiento limnológico más continuo. La composición de las principales comunidades planctónicas y bentónicas responde tanto a motivos biogeográficos o ambientales, como a la presión humana. Se analiza el impacto producido en algunas lagunas por el turismo y la ganadería, el represamiento, los vertidos de un refugio, la erosión en la cuenca, la introducción de un salmónido o por un posible calentamiento climático. Las medidas adoptadas para mitigar algunos de estos impactos o restaurar sus condiciones originales son descritas y evaluadas.

Palabras clave: Lagunas de alta montaña, cambios ambientales, impactos humanos, paleolimnología, restauración de lagunas, limnología regional, Sistema Central Español. 


\section{INTRODUCTION}

The study of natural processes that guide the functioning of ecosystems is a difficult task for researchers in the 21 st century, due to the direct or indirect interference of human activities. The location of semi-pristine ecosystems in which to study the Earth's processes at different scales and its response to global environmental changes is a goal of recent interdisciplinary studies in the field of ecology (N.R.C., 2005). The aquatic ecosystems are a key to global change studies, due to the sensitivity and vulnerability of their biological communities and their ecological processes (Poff et al., 2002). In order to detect trends in the climate or in ecological processes, both natural and resulting from human activity, researchers have turned to high altitude aquatic ecosystems, as sites not altered directly (Marchetto \& Rogora, 2004; Livingstone, 2005). Their value as sensors of environmental change come from a series of characteristics that set them apart from other aquatic systems: low mineralization and buffering capacity, low nutrient concentration ( $\mathrm{N}$ compounds), accumulation of trace metals and organic compounds in the food chain, and the predicted higher reaction to global warming in alpine areas (MoralesBaquero et al., 2001). These aquatic ecosystems, present in most continents, have been studied as sensors of distinct environmental processes: acidification (Battarbee \& Renberg, 1990; Camarero et al., 1995a, b; Marchetto, et al., 1995; Wögrath \& Psenner, 1995; Tait \& Thaler, 2000), climate change (Hauer et al., 1997; Lami et al., 1998; Battarbee et al., 2002; Abbott et al., 2003), dispersion of atmospheric contaminants (Fernández et al., 2002; Carrera et al., 2002; Curtis et al., 2005), land use changes (Hausmann et al., 2001) and erosion processes (Toro \& Granados, 2002).

The management and control of the factors that induce environmental changes, as well as informing society about the magnitude of such changes and the effectiveness of the adopted measures, require extensive, continuous and precise monitoring, which helps detect, monitor and link these variations to the parameters that quantify the environmental conditions (Parr et al., 2003). The researcher should make use of three basic tools to reach this goal: 1) reliable historical information, 2) long term monitoring networks, and 3) paleoecological studies. The first two tools are scarce in most of our alpine systems, which, due to their remote character and harsh environmental conditions, have been seldom visited in the past, with few rigorous research done until the 1980s (Pascual et al., 2000). In order to make up for the scarcity of long-term environmental studies, scientists have developed complex mathematical models, both predictive as reconstructive, in different spatial and temporal scales, for distinct geographical zones (Castro et al., 1995; Arpe \& Roeckner, 1999). Nevertheless, it is essential to be able to use historical and current information, organized in databases, as calibration for the models (Richardson \& Berish, 2003) or in the paleoecological reconstructions (Veski et al., 2005).

In the alpine regions of the Iberian Peninsula, there are few long-term studies with sufficient time scale to detect natural ecosystems responses to regional environmental changes. The meteorological station located in Puerto de Navacerrada (1890 m a.s.l., Guadarrama Mountains, Central Range) (Martinez-Molina et al., 1984) has one of the longest databases, with more than 50 years of measurements. The paleoecological studies performed in the Iberian Peninsula are contributing valuable alternative data to the task of reconstructing our past, and though not homogenously distributed, have been established in numerous locations. A large part of these studies have been developed in alpine regions, contributing to the knowledge of past climate change and its effects in the ecosystems in the Iberian Peninsula (Toro et al., 1993; Ruíz-Zapata et al., 1997; Monserrat, 1992; Peñalba et al., 1997, Catalan et al., 2002), land use changes on the regional scale (Luque \& Julia, 2002), long distance contaminant dispersion (Camarero et al., 1995b), or human activity effects on a local scale (Toro \& Granados, 2002).

The present work compiles the main studies performed during the past 15 years by a research team in the Ecology Department of the 
Universidad Autónoma de Madrid, on the Central Range (Guadarrama and Gredos Mountains) high mountain lakes and wetland ecosystems, in the Iberian Peninsula. The focus of the research done has been the local and regional characterization of these systems from a limnologic standpoint, as well as their utilization as environmental change sensors in the local and regional scales for natural and human induced processes. The results obtained have served as support for different measures adopted in the management and restoration of the natural systems studied.

\section{The historic scientific heritage. Ramon Margalef's contribution}

Even though these alpine ecosystems are considered today pristine sites, free from impacts or considerable human activity, it was in the period of the first explorers (19 ${ }^{\text {th }}$ century and the first half of the $20^{\text {th }}$ century) that these ecosystems were in their most natural condition. The origins of scientific research in high mountain lakes and wetlands in Spain can be traced to this period, motivated by an excursionist illusion and seeking similarities with the studies done in the Alps lakes (Casado, 2000).

Some of the first scientific or naturalistic explorations of the Central Range mountain lakes cited in the literature date back to the $19^{\text {th }}$ century (Aznar, 1839; Pictet, 1865) and the first half of the 20th century (Azpeitia, 1911; Obermaier \& Carandell, 1917; Arevalo, 1921, 1931, Pardo, 1932, 1948). The first aquatic species inventories are found in the works of González-Guerrero (1927, 1929a, b, 1965) and Caballero $(1944,1950)$ on phytoplankton.

The Peñalara lakes were also visited by the best known Spanish limnologist, Ramón Margalef. On April 29, 1949, with his friend Emilio Fernández Galiano, Margalef collected
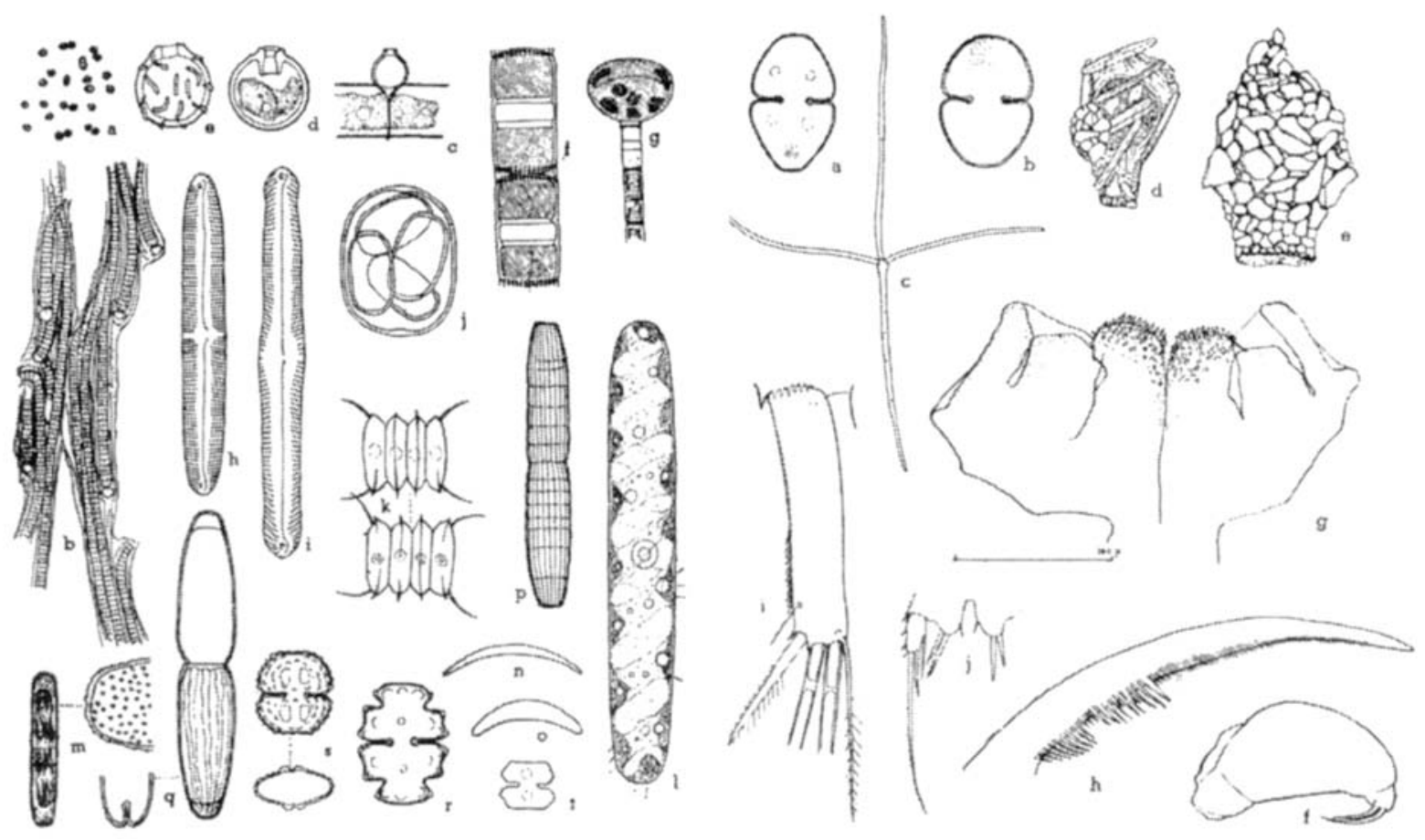

Figure 1. Reproduction of Ramon Margalef's draws of aquatic organisms found in several lakes, streams and mires in Peñalara Massif in 1949. (Source: R.Margalef. 1949. Datos para la hidrobiologia de la Sierra de Guadarrama. Publ. Inst. Biol. Apl., Tomo VI: 5-21). Reproducción de los dibujos realizados por Ramón Margalef de los organismos acuáticos encontrados en varias lagunas, arroyos y turberas del Macizo de Peñalara en 1949. (Fuente: R.Margalef. 1949. Datos para la hidrobiologia de la Sierra de Guadarrama. Publ. Inst. Biol. Apl., Tomo VI: 5-21). 


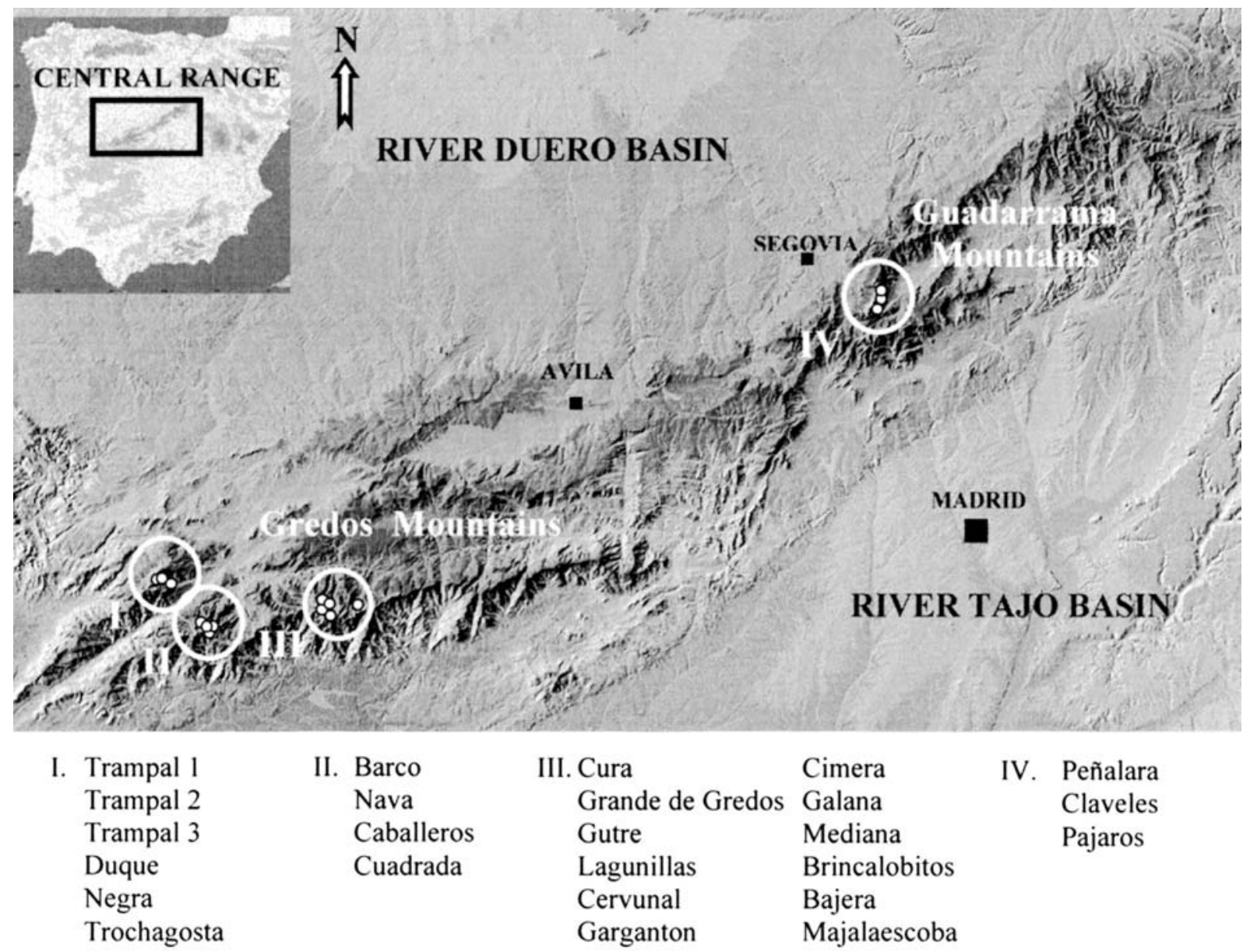

Figure 2. Location of high mountain lakes in Spanish Central Range (Guadarrama and Gredos Mountains). Localización de las lagunas de alta montaña del Sistema Central, España (Sierras de Guadarrama y Gredos).

water samples from several lakes, streams and mires, in order to supply new biogeographic data on Iberian fresh water organisms. The results of this excursion, with an extensive list of organisms identified, were published in that same year in a paper entitled "Datos para la hidrobiologia de la Sierra de Guadarrama" [Data for the hydrobiology of Guadarrama Range] (Margalef, 1949). The historical data provided by Margalef in this work have served as valuable reference for recent studies, such as the effects of the introduction of the brook trout in the lake's community, with the description of the species present previous to the introduction of this salmonid. Margalef mentioned the absence of phanerogams and mosses in the lake, as well as the absence of fish. His biological descriptions encompass phytoplankton, zooplankton, phytobenthos (herpon and pecton) and macroinvertebrate species, including detailed morphological and taxonomic notes on some species, as well as some drawings (Fig. 1).

\section{STUDY AREA}

The Central Range, with a ENE-WSW orientation, divides the two Iberian Peninsula plateaus corresponding to the basins of the Duero River to the north, and Tajo River, to the south (Fig. 2). This system is formed by the following mountains, from the northeast: Ayllón (1691 m), 
Somosierra (2250 m), Guadarrama (2430 m), Gredos $(2592 \mathrm{~m})$, Béjar $(2401 \mathrm{~m})$, Peña de Francia $(1723 \mathrm{~m})$, Gata $(1519 \mathrm{~m})$ and, in Portugal, the Estrela and Lousa (1991 m). It is constituted primarily by Paleozoic Precambrian igneous rocks (granite and gneiss) and metamorphic rock slates, with very low solubility. Lakes are only found in the Guadarrama, Gredos and Estrela Mountains, where the landscape forming role of the glaciers was more intense. The results obtained in projects in the Guadarrama and Gredos ranges are presented in this work. Information on the Estrela mountain range lakes can be found in the work of Boavida (2000). Most of the glaciers of the Gredos Mountains were located on the northern slope, where all of the alpine lakes are situated. Their watersheds flow into the Duero River basin, in the Northern Iberian Plateau (Fig. 2). The glacial impacts were much less in the neighbouring Guadarrama Mountains. The high snow accumulation by the wind in the leeward slopes facing southeast originated the development of these small glaciers of ice masses on south-facing slopes (SanzHerraiz, 1977). Sanz-Herraiz (1988, 1999) and Pedraza et al. (2004) describe and interpret glacier's geomorphology in Peñalara Massif. Besides a considerable number of ponds, there are three main lakes which represent the circus and moraine types, whose watersheds flow into the Tajo river basin in the South Iberian Plateau (Fig. 2). The precipitation reaches maximum values above $2000 \mathrm{~mm}$ in some places in the Central Range. The mean annual precipitation in the Peñalara Massif (Guadarrama Mountains) is $1350 \mathrm{~mm}$, ranging between $780 \mathrm{~mm}$ and $2380 \mathrm{~mm}$, and maximum and minimum mean values of temperature are $20{ }^{\circ} \mathrm{C}$ and $-5{ }^{\circ} \mathrm{C}$ respectively (data from the period of 1946-2004: Meteorological Station of Puerto de Navacerrada, 1890 m.a.s.l. National Institute of Meteorology). There are no meteorological stations in the high mountain zone of the Gredos Mountains that could collect local data, but bulk precipitation is estimated to be slightly higher and temperature values slightly lower that in the Guadarrama Mountains. The timberline is situated at an altitude of 1900-2100 m.a.s.1.
(Martínez, 1999), with the Pinus sylvestris pine as the forest community that reaches the highest altitude in all of the Central Range (Luceño y Vargas, 1991). The high mountain zone, the focus of this study, has two vegetation zones: the oromediterranean, typical of "piorno serrano" (Cytisus oromediterraneus) and the cryoromediterranean, represented by the psychroxerophilous grassland. Most of the lake basin has little vegetation or developed soils.

The two groups of lakes studied in the Central Range are under the protection of two regional parks: the Peñalara Natural Park, reclassified in 1990 from the former National Interest Natural Site of 1930, and the Gredos Mountains Regional Park, created in 1996. The Peñalara Massif wetlands are in the process of approval for inclusion in the RAMSAR list of international importance.

\section{METHODS}

The limnologic samples have been collected from 1991 to the present with variable intervals, according to the lakes sampled. The methodology used was based on the following references: morphometric parameters according to Häkanson (1981), water chemistry following standard methods and protocols (APHA, 1992; Catalan \& Camarero, 1988; Catalan Lafuente, 1990; Krol et al., 1997; Wathne \& Hansen, 1997), plankton analyses (Sournia, 1978; De Hoyos \& Negro, 2001), pigments (Jeffrey \& Humphrey, 1975), macroinvertebrates (Toro \& Granados, 1998), sediment sampling, dating and analyses (Battarbee, 1986; Appleby et al., 1986; Walker, 1987; Glew, 1988, 2001), and sediment traps (Wathne \& Hansen, 1997). Besides that, the methodology used in the various specific environmental change studies is described in detail in the following works: effects of the brook trout introduction (Granados \& Toro, 2000b), study of erosion in a lake basin (Toro \& Granados, 2002), effects of wastewater refuse (Robles et al., 2000), and the study of subfossil diatoms and chironomids as sensors of recent changes (Toro et al., 1993; Granados \& Toro, 2000a). 


\section{REGIONAL LAKE LIMNOLOGY IN THE SPANISH CENTRAL RANGE}

\section{Morphometrics and genesis}

The Central Range morphology is a result of several morphoclimatic processes, with a predominance of fluvial and glacial processes. The end of glaciers took place around 10.000 years ago (De Pedraza \& López, 1980). The lakes were formed by the melting of ice and snow in the depressions, and by water retention by the lateral or frontal moraines, that acted as dams. Toro \& Granados (2001), based on a previous classification done by De Pedraza \& López (1980), developed a typology of the lake basins based on their genesis (glacial geomorphology) and morphometrics, that conditions the ecological functioning of each of the lake

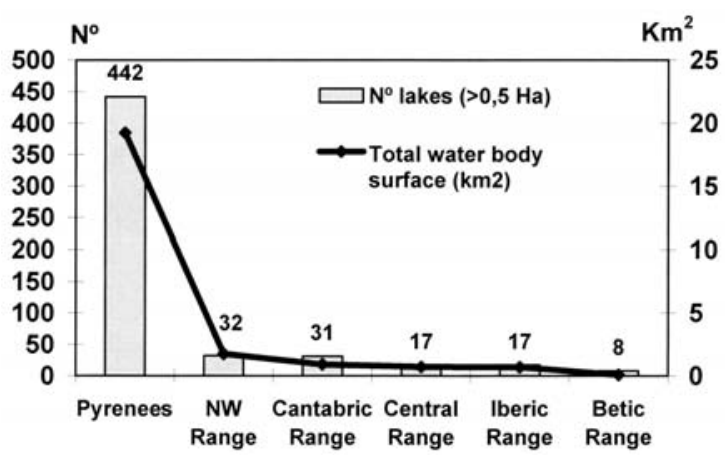

Figure 3. Distribution and total surface area $\left(\mathrm{km}^{2}\right)$ of high mountain lakes (lake surface area $>0.5$ ha) in the mountain ranges of the Iberian Peninsula (adapted from Pascual et al., 2000). Distribución y superficie total $\left(\mathrm{km}^{2}\right)$ de los lagos de alta montaña (superficie mayor de 0.5 ha) en los sistemas montañosos de la Península Ibérica (adaptado de Pascual et al., 2000).

systems (Table 1): circus (4 lakes), glacial valley bottom (10), "hoyas" (4), fluvial (2) and

Table 1. Morphometric characteristics of high mountain lakes in Gredos and Guadarrama mountains (Central Range, Iberian Peninsula). Características morfométricas de las lagunas de alta montaña de las Sierras de Gredos y Guadarrama (Sistema Central, Península Ibérica).

\begin{tabular}{|c|c|c|c|c|c|c|c|c|c|}
\hline Lake & $\begin{array}{c}\text { Coord. } \\
\text { UTM }\end{array}$ & $\begin{array}{c}\text { Altitude } \\
\text { (m) }\end{array}$ & $\begin{array}{c}\text { Typology } \\
\text { (genesis)* }\end{array}$ & $\begin{array}{c}\text { Watershed } \\
\text { Area } \\
\text { (ha) }\end{array}$ & $\begin{array}{c}\text { Surface } \\
\text { Area } \\
\left(\mathrm{m}^{2}\right)\end{array}$ & $\begin{array}{c}\text { Lake } \\
\text { Volume } \\
\left(\mathbf{m}^{3}\right)\end{array}$ & $\begin{array}{c}\text { Lake } \\
\text { Perimeter } \\
\text { (m) }\end{array}$ & $\begin{array}{c}\text { Max. } \\
\text { Depth } \\
\text { (m) }\end{array}$ & $\begin{array}{c}\text { Residence } \\
\text { Time } \\
\text { (days) }\end{array}$ \\
\hline \multicolumn{10}{|l|}{ Guadarrama } \\
\hline Peñalara & 30TVL190215 & 2019 & Circus & 44.2 & 5779 & 11563 & 364 & 4.7 & 9.0 \\
\hline Claveles & 30TVL201231 & 2119 & Moraine & 12.6 & 6263 & 11560 & 440 & 2.6 & -- \\
\hline Pájaros & 30TVL200239 & 2170 & Hoya & 4.8 & 4943 & 1021 & 447 & 0.5 & 5.2 \\
\hline \multicolumn{10}{|l|}{ Gredos } \\
\hline Duque & 30TTK716650 & 1595 & Bottom valley & 760.0 & 203295 & 1644000 & 2440 & 21.5 & 46.4 \\
\hline Cura & 30TUK159614 & 1750 & Moraine & 4.8 & 2000 & -- & 150 & 0.4 & - - \\
\hline Barco & 30TTK785567 & 1785 & Bottom valley & 374.4 & 74781 & 357702 & 1250 & 14.8 & 20.5 \\
\hline Cervunal & 30TUK054630 & 1815 & Moraine & 6.3 & 4200 & - - & 235 & 1.0 & -- \\
\hline Majalaescoba & 30TUK042617 & 1830 & Fluvial & 403.1 & 2615 & - & 231 & 1.2 & -. \\
\hline Lagunilla & 30TUK035621 & 1915 & Hoya & 62.5 & 5437 & - - & 362 & 1.7 & -. \\
\hline Grande Gredos & 30TUK064585 & 1935 & Bottom valley & 325.0 & 63076 & 145837 & 2423 & 6.5 & 9.6 \\
\hline Nava & 30TTK810565 & 1945 & Circus & 62.4 & 92268 & 425500 & 1100 & 11.0 & 146.4 \\
\hline Caballeros & 30TTK798553 & 2025 & Circus & 58.0 & 14027 & 40840 & 450 & 5.2 & 15.1 \\
\hline Trampal 3 & 30TTK697658 & 2025 & Bottom valley & 188.0 & 62042 & 599830 & 1140 & 20.8 & 68.5 \\
\hline Negra & 30TTK 697643 & 2070 & Hoya & 2.3 & 1450 & - & 180 & 2.0 & - - \\
\hline Cuadrada & 30TTK 787557 & 2085 & Hoya & 42.6 & 7773 & 10525 & 380 & 2.5 & 5.3 \\
\hline Gargantón & 30TUK054594 & 2085 & Fluvial & 99.0 & 441 & - - & 250 & 1.5 & -- \\
\hline Bajera & 30TUK044605 & 2100 & Bottom valley & 120.0 & 9599 & 14974 & 505 & 4.2 & 2.7 \\
\hline Brincalobitos & 30TUK042600 & 2100 & Bottom valley & 106.3 & 981 & 1391 & 150 & 3.3 & 0.3 \\
\hline Trampal 2 & 30TTK692657 & 2115 & Bottom valley & 70.0 & 15352 & 37715 & 650 & 4.25 & 11.6 \\
\hline Trampal 1 & 30TTK689658 & 2125 & Bottom valley & 54.2 & 6063 & 8780 & 400 & 2.9 & 3.5 \\
\hline Mediana & 30TUK043602 & 2130 & Bottom valley & 97.9 & 3240 & 4693 & 295 & 2.4 & 1.0 \\
\hline Galana & 30TUK045604 & 2135 & Bottom valley & 92.3 & 15251 & 54353 & 680 & 7.6 & 12.6 \\
\hline Cimera & 30TUK040596 & 2140 & Circus & 75.6 & 44900 & 216890 & 1275 & 9.4 & 61.6 \\
\hline Trochagosta & 30TTK691652 & 2210 & - & 19.5 & - - & - - & - & - - & - - \\
\hline Gutre & 30TUK045594 & 2300 & Hoya & 3.1 & 960 & - & 175 & 2.0 & - - \\
\hline
\end{tabular}

* Hoya: local term for small lakes or ponds located at glacial valleys bottom or depressions (Toro \& Granados, 2001). 


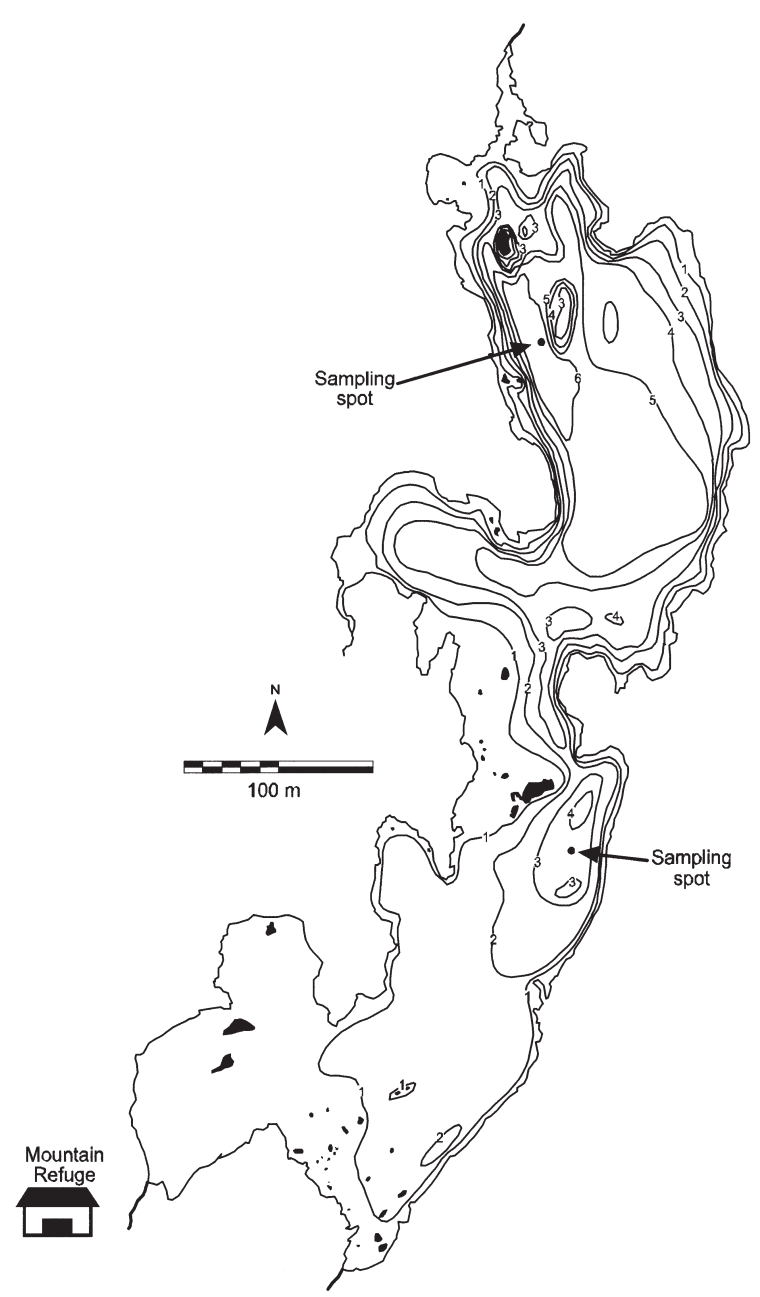

Figure 4. Bathymetric map of Grande de Gredos Lake with location of sampling sites and mountain refuge. Mapa batimétrico de la laguna Grande de Gredos con la ubicación de los puntos de muestreo y del refugio de montaña.

moraine (3). The lakes of the Central Range have smaller dimensions when compared to other mountain systems in the Iberian Peninsula, such as the Pyrenees or the Cantabric Range, having much fewer water bodies (Fig. 3). This reduced size determines a greater influence of the external environmental conditions on the water bodies. The lakes with greater surface areas are the ones that were dammed: Duque (20.3 ha.), Nava (9.22 ha.) and Barco (7.47 ha.), with a considerable increase from their original surface areas. The larger natural lakes are the Grande de Gredos
(6.3 ha.) and the Cimera (4.49 ha.), both in the Gredos Mountains. In the Guadarrama Mountains, the largest permanent lake is the Grande de Peñalara (0.57 ha.), although Claveles, a temporary lake, is slightly larger (0.62). Table 1 contains the main morphometric parameters of Central Range lakes. Their altitudes range between $1600 \mathrm{~m}$ and $2300 \mathrm{~m}$, with a mean altitude of $1994 \mathrm{~m}$, and $60 \%$ of the lakes situated above $2000 \mathrm{~m}$.

The Grande de Gredos Lake has the most peculiar morphometrics of all the Central Range lakes, in which the erosion of the ice on a long bottom glacier circus generated two depressions, originating two lake basins connected by a narrow strait (Fig. 4). The rocky nature of the basin generated a very sinuous perimeter, uncommon in these alpine lakes, giving it the longest perimeter of all the Central Range lakes ( $>2400 \mathrm{~m}$ ) and the largest surface area of the lakes that are not dammed (6.3 ha). The rest of the lakes have a single basin. Most of the lake catchment have steep slopes, with a predominance of partially fractured bedrock and moraines and talus zones with smaller sized materials, as well as small areas occupied by psychroxerophilous alpine fields, or small depressions occupied by ponds, wetlands or peatlands. There are few catchments with considerable alpine shrub vegetation on the less steep slopes (Duque, Barco, Caballeros, Cervunal, Majalaescoba and Peñalara). As a representative example, the Peñalara Lake watershed has $63 \%$ of its surface occupied by bedrock and talus, $29 \%$ by mountain scrubs (Cytisus oromeditarraneus, Juniperus communis ssp. alpina), some $6 \%$ by psychroxerophilous grassland (mainly Festuca curvifolia) and $2 \%$ by Nardus stricta wet meadows.

The bottom of most of the lakes is mainly silty, with a relatively low organic matter content (13\% Peñalara, $16 \%$ Cimera, $19.5 \%$ Grande de Gredos) with a higher percentage of sandy material at the shores and at stream inlets, with the presence of blocks or scattered stones, usually at the foot of the hills, talus or slide rocks. One exception is the Claveles Lake (Guadarrama Mountains), loca- 


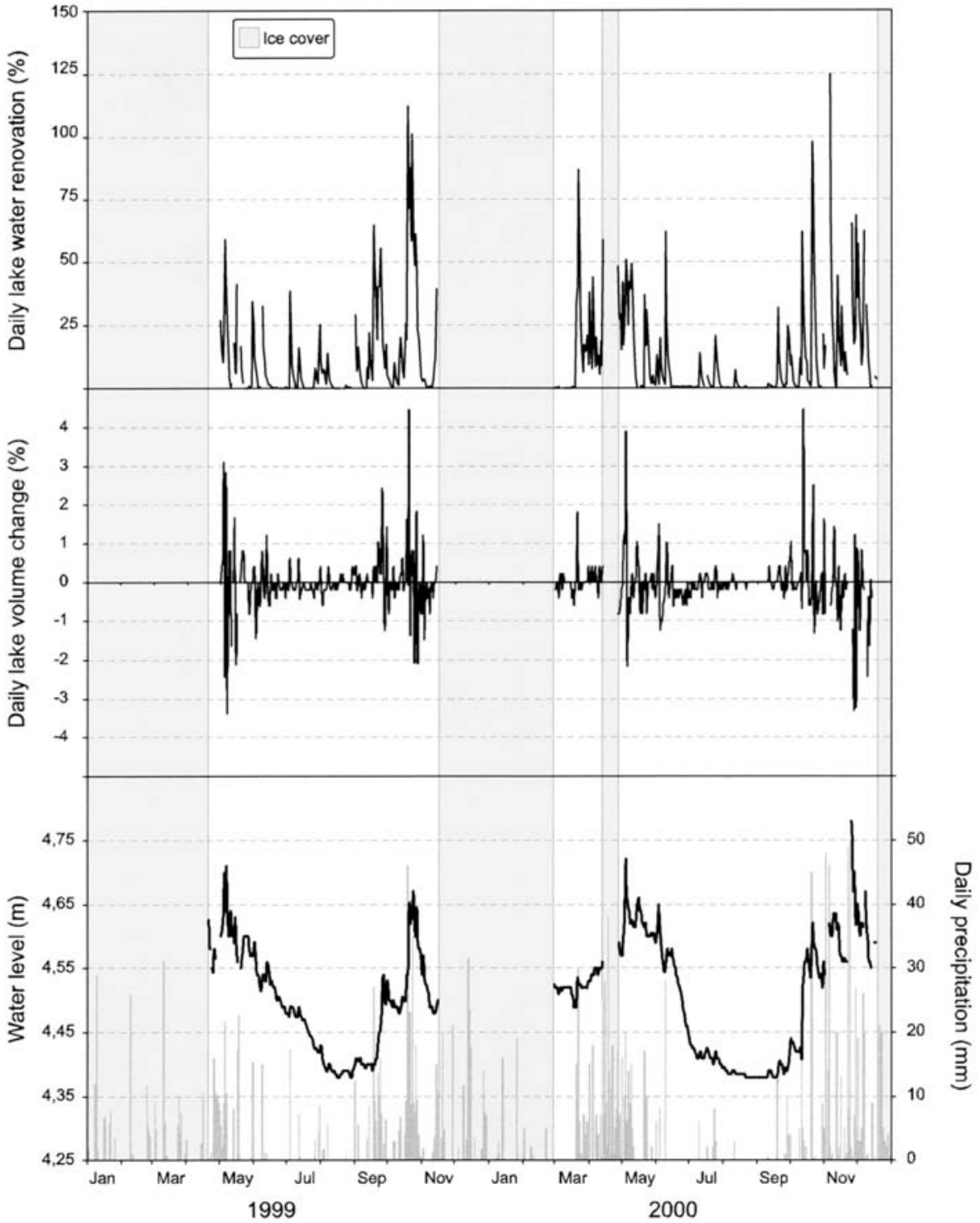

Figure 5. Lake level, volume and turnover rate responses to the water inflow from snow melting and liquid precipitation in Peñalara Lake for 1999 and 2000. Respuesta del nivel, volumen y tasa de renovación de la laguna de Peñalara a la entrada de agua procedente de la fusión de la nieve y de la precipitación líquida durante 1999 y 2000.

ted on a moraine arch, which gives it a temporary characteristic, due to the substrate permeability. This lake's bottom is lined with medium sized rocks (0.1-1 $\mathrm{m}$ in diameter) with almost no silt or fine material, probably due to the small catchment slope of rocky nature and the absence of water in the summer months, when the biological productivity is greatest in these lakes (Toro et al., 2000).

\section{Hydrology}

All the Central Range lakes, except for the Cervunal and Negra lakes, have a superficial water outlet and one or two main surface water inlets and several intermittent streams, with greater flow during the thaw period or heavy storms. With the exception of the large lakes (Barco, Duque, Nava, Trampal 3 and Cimera), 
the mean annual turnover rate is less than 15 days (Table 1), reaching minimums of less than 1 day during the ice cover melting (the precipitation as snow can exceed $60 \%$ of the total annual precipitation; Puerto de Navacerrada Meteorological Station data, INM). The interannual and seasonal variation in turnover rate is apparent in the data collected in the Peñalara Lake basin during a period of several years. Figure 5 reflects the lake level, volume and turnover rate responses to the phenomena of snow melt and liquid precipitation during the studied period, picked after the thawing and the autumn rains, and with minimum values during summer. Isolated precipitation events during the summer can cause an increase of between 4 and $15 \%$ of the lake water volume in only one day (a precipitation of $32 \mathrm{~mm}$ caused a rise in the water level of $15.5 \mathrm{~cm}$ in July 1998), with theoretical lake turnover rates of up to $183 \%$ for October 19, 2001 (almost twice its volume). It is relatively common to have periods of one or more days with a turnover rate of over $50 \%$ of the water retained in the lake, in response to intense precipitation.

The water discharge coming from the snowpack responds rapidly to the increased spring air temperatures, generating a hydrogram with strong daily fluctuations during the days of maximum melting, due to the day/night temperature difference. Figure 6 a shows the Peñalara Lake outlet stream hydrogram during a typical thawing month, with a diminishing fluctuation range with temperature or by the snowpack disappearance. On the other hand, the typical hydrogram during the summer period is less fluctuating, though isolated sharp water level increments can be observed, resulting from heavy storms (Fig. 6b), returning to the normal flow 2 or 3 days later. It has been assumed, for the hydrological balance and turnover rate estimations, that the precipitation falling on a watershed, as well as the snowpack melting water, run almost entirely on the surface of the soil. Nevertheless, recent studies with markers have shown the important role of the "soil and talus reservoirs" in high mountain watersheds, where up to $50 \%$ of the snow melt water is infiltrated in the terrain and later discharged in
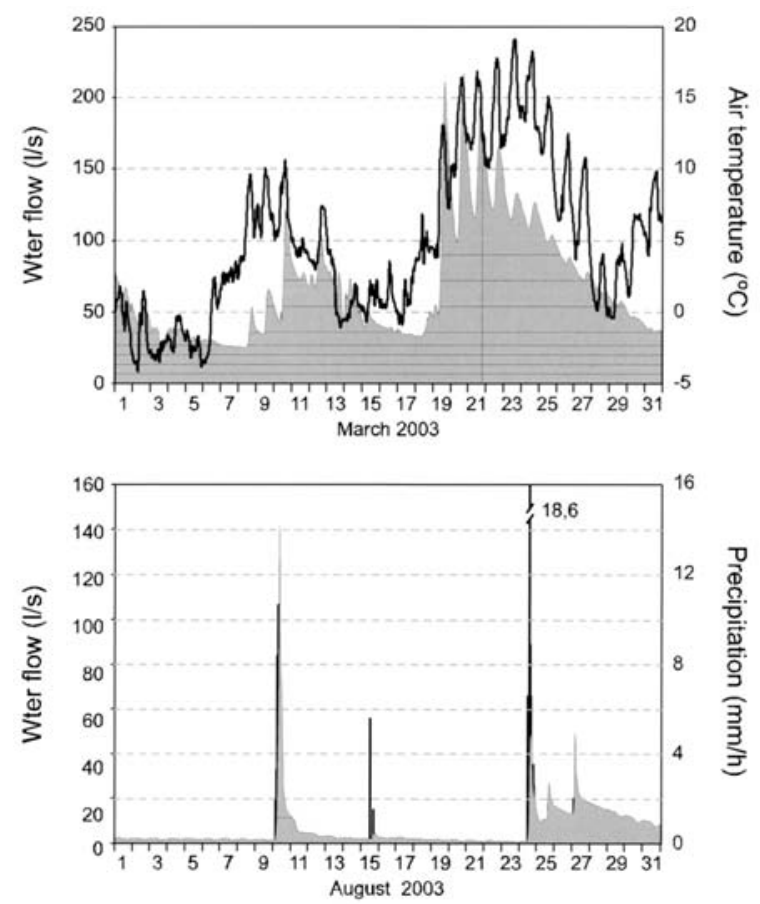

Figure 6. Peñalara Lake outlet stream hydrogram during: a) a typical thaw month; b) a summer month with heavy storms. Hidrograma del arroyo de salida de la laguna de Peñalara durante: a) un mes típico de deshielo; b) un mes estival con fuertes tormentas.

the watershed streams. This promotes the chemical interaction of the water and the substrate during the subsoil storage, noticeably affecting the water chemical composition (Williams et al., 2005). The storage capacity of the studied Central Range watersheds is not known, but it probably varies according to each watershed's size and lithological characteristics. Nevertheless, base flow for Peñalara Lake watershed in summer is less than $5 \mathrm{~L} \mathrm{~s}^{-1}$, and the lake outlet uses to become dry after a $30-45$ days period without rainfall, therefore underground water storage period or storage capacity would not be so large.

During periods of intense turnover, the smaller lakes' limnological characteristics are closer to a lotic ecosystem (e.g. lakes Majalaescoba, Brincalobitos, Gargantón), with predominance of watershed material transport by erosion and of aquatic organisms drift, with a total instability of the water column (turbulent heat and flux distribution) and a grater ion and nutrient dilution. The change magnitude of the water turn- 


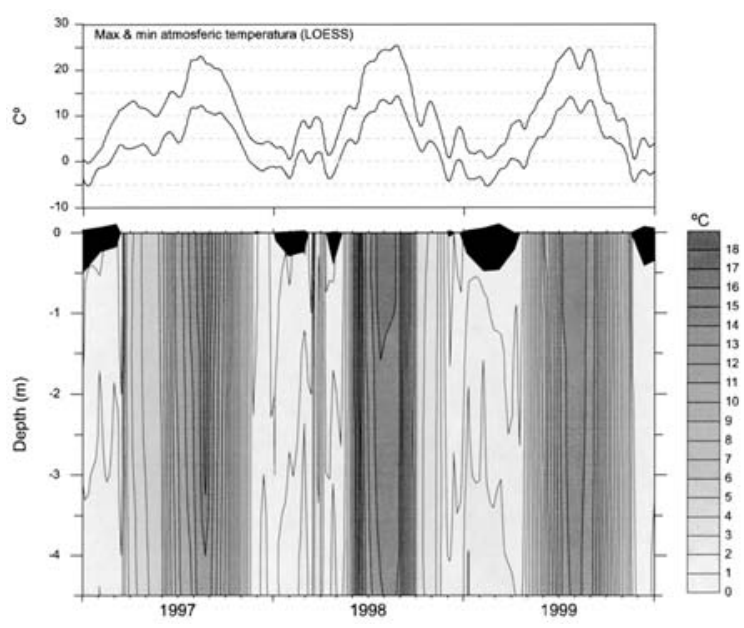

Figure 7. Isopleth diagram of temperature at Peñalara Lake during the period 1997-1999. Diagrama de isopletas de temperatura en la laguna de Peñalara durante el periodo 1997-1999.

over rates depends mainly on two meteorological variables: temperature and precipitation, just as shown in the figure 6 hydrograms. Therefore, changes in precipitation and temperature regime in these high mountain watersheds (e.g. as a consequence of a possible climate change) would noticeably affect the water flow regime, and ultimately, the water availability as a resource throughout the year (Williams et al., 2005).

\section{Water temperature}

The physical stability of the water column, as well as it's thermal inertia as related to the air temperature in the lakes studied are smaller than in other deeper alpine lakes, due to their smaller size. Mixed water column periods predominate over stratified ones (Fig. 7). The water thermal response to air temperature changes is fast: in summer, with maximum air temperatures above $25^{\circ} \mathrm{C}$, the superficial water layer of some lakes reaches temperatures of $18-20^{\circ} \mathrm{C}$, although there is not a stable and lasting actual thermocline in most lakes. In water depths of less than 10-15 m, stable stratification only occurs under ice cover (Fig. 7). Figure 8 illustrates the summer water temperature profiles in the Central Range's deepest lakes. It can be observed that the three dammed lakes (Duque, Trampal 3 and Barco) have a greater surface/bottom thermal gradient, since there's no natural water column turnover during the summer. Duque, the deepest lake, stands out, presenting a clear thermal stratification with an evident thermocline. During the autumn, temperatures progressively drop, and the water column is mixed by the rain water input, up to the formation of an ice cover. Lakes freeze over in November or December, coinciding with a period of at least 3 or 4 days with maximum air temperatures below $0{ }^{\circ} \mathrm{C}$, beginning the winter inverse stratification (Fig. 7). During the winter period, if the ice cover thickness is not thick enough and minimum air temperature increase over $0{ }^{\circ} \mathrm{C}$ for a few days, it can melt completely until air temperature decreases again (Fig. 7). The ice cover duration in the lakes varies spatially and temporally. Besides precipitation, temperature, winds and radiation factors during the winter months, the watershed's relief can prolong the duration of the ice cover, by obstructing direct radiation incidence on the lake surface. The Cimera Lake (Gredos Mountains) is a clear example of this. There is a distinctive escarpment in the south side, which exerts a noticeable shading effect on the lake. Figure 9 shows the percentage of reduction of the potential incident radiation (direct radiation) on the lake by the effect of the surrounding relief. As opposed to the north shore, the south shore does not receive direct solar radiation from October $7^{\text {th }}$ to March $7^{\text {th }}$ (there's only diffuse solar radiation incidence) and receives less than $10 \%$ of the potential radiation during five months of the year. On the other hand, the potential radiation only drops noticeably for one month a year at the north shore, with a relief-related reduction of only $40 \%$. This incident radiation asymmetry causes a delay in the south shore ice cover melting of 1-2 months compared to the north shore, and the lake water temperature has a marked north-south gradient during the melting, with temperatures of up to $12^{\circ} \mathrm{C}$ in the north side while the south shore still has a considerable ice cover. The possible ecological implications in the benthic shore habitat are evident: 1) water temperature differences between 8 and $12{ }^{\circ} \mathrm{C} ; 2$ ) ice cover shading effect on the benthic habitat, reducing primary production; and 3 ) this situation can last up to two months. The relief effect is less important in the Peñalara lakes, due 
to their south-southeast orientation, than in the Gredos lakes. Due to this, the mean ice cover duration is much more prolonged in the Gredos lakes (e.g.: 115 days in the Peñalara Lake, 185 days in the Grande de Gredos Lake, and 220 days in the Cimera Lake). The formation and melting of the ice cover are also quite different between the lakes of the two massifs: they form in November-December in Gredos, completely melt in June-July (August 1996 in Cimera); the ice cover period in Peñalara goes from December-
January to March-April (Fig. 7). Ice cover thicknesses of $142 \mathrm{~cm}$ (March 1996) and $165 \mathrm{~cm}$ (March 1991) have been recorded for Peñalara Lake, with the lowest maximum being approximately $30 \mathrm{~cm}$ (winter of 2001-2002). In the Cimera Lake (Gredos Mountains), the maximum ice cover thicknesses registered were $>280 \mathrm{~cm}$ in the winter of 1996-1997 and $187 \mathrm{~cm}$ in the winter of 1997-1998. In the former, the ice cover was composed of up to 10 layers with different thickness, texture and water content.

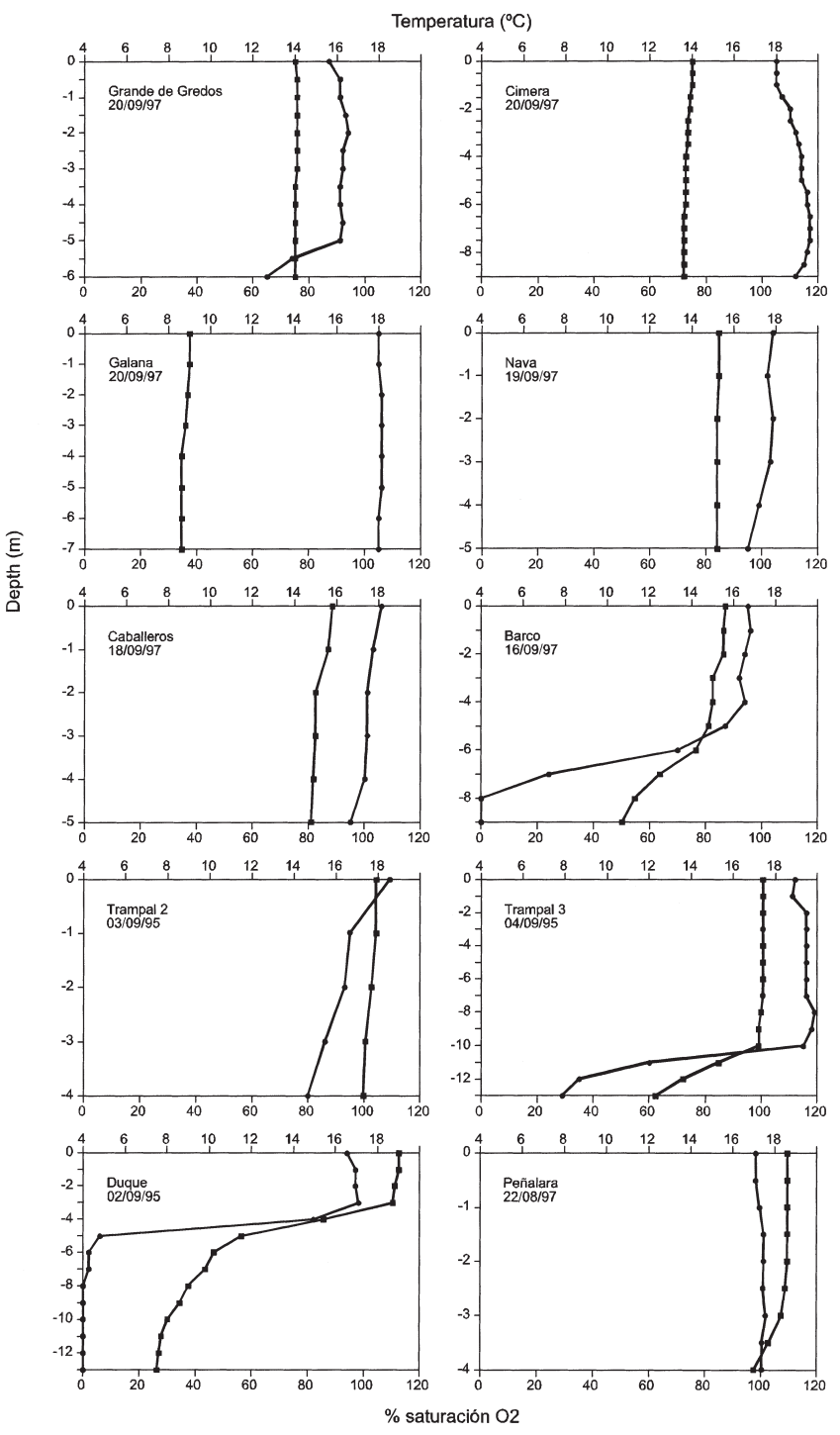

Figure 8. Profiles of water temperature and percentage of dissolved-oxygen saturation in the Central Range's deepest lakes in summer months. Perfiles de temperatura y porcentaje de oxígeno disuelto en las lagunas más profundas del Sistema Central en los meses de verano. 


\section{Dissolved oxygen}

Under natural conditions, the water column oxygen concentration in the high mountain lakes is relatively high during the whole annual cycle, and is not a limiting factor for the biota's development. Dissolved oxygen saturation between 90 and $110 \%$ is common. There is an annual periodical fluctuation in the lake's surface layer, with maximum values in the winter (e.g. $10-12 \mathrm{mg} \mathrm{L}^{-1} \mathrm{O}_{2}$ ) and minimum values in the summer (e.g. 7$8 \mathrm{mg} \mathrm{L}^{-1} \mathrm{O}_{2}$ ). Nevertheless, during the ice cover period, there can be a progressive depletion of the oxygen in the water layer closer to the sediment (up to $0.1 \mathrm{mg} \mathrm{L}^{-1}$ ), as compared to the upper layers under the ice cover (up to $13 \mathrm{mg} \mathrm{L}^{-1}$ ). This process is directly proportional to the ice cover duration. If the trend for increasing mean air temperatures is happened and continued, the processes related to the ice cover dynamics could be affected, such as the oxygen depletion in the bottom. The intensity of this process could have been reduced since the beginning of the 1980 s, when the recent increase in air temperatures was first detected (Granados and Toro, 2000a). The melting of the ice cover produces a massive input of water in the lakes, mixing and renewing the whole volume in few days, reaching a maximum dissolved oxygen concentration in the deeper layers $\left(10-12 \mathrm{mg} \mathrm{L}^{-1}\right)$.

In some of the dammed lakes (Trampal 3, Barco and Duque), the general pattern in dissolved oxygen concentration during the summer is different than the rest of the lakes, diminishing in depth as the summer passes, reaching anoxic conditions in the deepest layers (Fig. 8). The oxygen depletion in the Trampal 3 Lake caused the formation of methane bubbles in the sediment, as a result of the organic matter degradation in anaerobic conditions. These bubbles are then release to the water column from structures in the sediment that resemble small volcanoes, with several centimetres of height. This inadequate condition for a high mountain oligotrophic lake can be caused by the following reasons: 1) the decrease in the natural turnover rate and its annual variation, increasing the quantity of organic matter that reaches the sediment (Whiteside, 1983); 2) the damming produces a higher fluctuation in the lake's water level eliminating the littoral aquatic vegetation and favouring the organic matter decomposition in the shore line with the alternation of dry/flooded periods, increasing the nutrient availability. The annual fluctuation in the water level can reach several meters in the dammed lakes, while in most natural lakes usually is less than $50 \mathrm{~cm}$.

\section{Hydrochemistry}

The chemical composition of the high mountain lakes is determined by several factors: weathering and biogeochemical processes, atmospheric inputs, biological processes in the lakes, and finally, hydrological variables such as the evaporation and turnover rates dynamics. The chemical composition values of the Central Range lakes (displayed data from end-summer samplings) are shown in Table 2. The mean water column conductivity of all the lakes studied is very low, fluctuating between $4 \mu \mathrm{S} \mathrm{cm}^{-1} 25^{\circ} \mathrm{C}$ in the lakes of the Cinco Lagunas circus (Gredos Mountains) and $22 \mu \mathrm{S} \mathrm{cm}^{-1} 25^{\circ} \mathrm{C}$ in the Peñalara Lake (Guadarrama Mountains) in the summer months. Nevertheless, there are remarkable fluctuations in the annual and interannual scales, depending mainly on the turnover rate (Fig. 10). The mean water $\mathrm{pH}$ is slightly acid (ranging between 6.2 and 6.8 ), and the mean alkalinity is very low (ranging

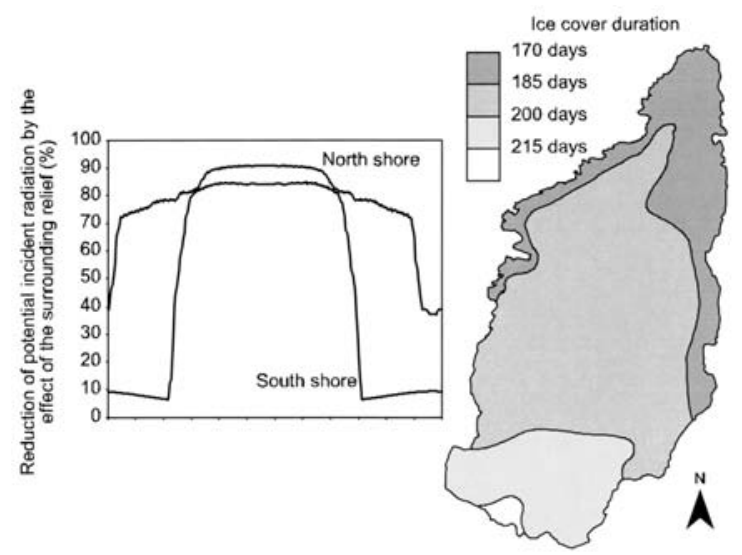

Figure 9. Percentage of reduction of the potential incident radiation (direct radiation) on Cimera Lake (Gredos Mountains) and mean duration of the ice cover over the different areas of lake. Porcentaje de reducción de la radiación potencial incidente (radiación directa) en la laguna Cimera (Sierra de Gredos) y duración media de la cubierta de hielo en las diferentes zonas de la laguna. 
between 40 and $60 \mu \mathrm{eq} \mathrm{L}^{-1}$ ), contributing to a very low buffering capacity in lake waters. The $\mathrm{pH}$ fluctuation range observed in some lakes (e.g. Peñalara) is very broad, with minimum values of 4.76 during the ice cover meltdown to maximum values of 7.70 during the summer months (Fig. 10). The maximum values for conductivity, $\mathrm{pH}$ and alkalinity during the year occur in the middle of the summer, under low turnover rates and high evaporation, with maximum primary productivity, increasing the concentration of dissolved ions in the water (Fig. 10). Even though pH over 7.5 is common in the Gredos Mountains lakes, a peak of 8.70 was registered in the Peñalara Lake, in the year 2000. With the autumn rains, the conducti- vity decreases temporarily until the ice cover formation, when the turnover rate falls to almost zero. A progressive gradient in conductivity, alkalinity and $\mathrm{pH}$ is formed then, with higher values in the deeper layers of the lake.

A significant correlation $\left(r^{2}=0.42 ; p<0.05\right)$ has been found between the ice cover duration and the increased conductivity under the ice cover for a 10 year time series in the Peñalara Lake. In the ice cover period in the years 19951996 and 2004-2005, when the ice cover was very thick, stable and long-lasting, there was a large increase in conductivity, reaching summerlike values $\left(>17 \mu \mathrm{S} \mathrm{cm} \mathrm{cm}^{-1} 25^{\circ} \mathrm{C}\right)$. On the other hand, during the ice cover period in 1997-1998 y

Table 2. End-summer chemical characteristics of the high mountain lakes in Central Range (Iberian Peninsula) (Gredos: 1995/1997; Guadarrama: 1999). Características químicas de los lagos de alta montaña del Sistema Central (Península Ibérica) a finales del periodo estival (Gredos: 1995/1997; Guadarrama: 1999).

\begin{tabular}{|c|c|c|c|c|c|c|c|c|c|c|c|c|c|c|}
\hline Lake & pH & $\begin{array}{c}\text { Cond. } \\
\mu \mathrm{S} / \mathrm{cm} \\
25^{\circ} \mathrm{C}\end{array}$ & $\begin{array}{l}\mathrm{Ca}^{2+} \\
\mu \mathrm{eq} / \mathrm{l}\end{array}$ & $\begin{array}{l}\mathrm{Mg}^{2+} \\
\mu \mathrm{eq} / \mathrm{l}\end{array}$ & $\begin{array}{c}\mathrm{Na}^{+} \\
\mu \mathrm{eq} / \mathrm{l}\end{array}$ & $\begin{array}{c}\mathrm{K}^{+} \\
\boldsymbol{\mu e q} / \mathbf{l}\end{array}$ & $\begin{array}{c}\text { Alk } \\
\mu \mathrm{eq} / \mathrm{l}\end{array}$ & $\begin{array}{l}\mathrm{SO}_{4}^{2-} \\
\mu \mathrm{eq} / \mathrm{l}\end{array}$ & $\begin{array}{c}\mathrm{Cl}^{-} \\
\mu \mathrm{eq} / \mathrm{l}\end{array}$ & $\begin{array}{l}\mathrm{NO}_{3}^{-} \\
\mu \mathrm{gN} / \mathrm{l}\end{array}$ & $\begin{array}{l}\mathrm{NH}_{4}^{+} \\
\mu \mathrm{gN} / \mathrm{l}\end{array}$ & $\begin{array}{c}\mathrm{TN} \\
\mu \mathrm{gN} / \mathrm{l}\end{array}$ & $\begin{array}{c}\text { TP } \\
\mu \mathrm{g} / \mathrm{l}\end{array}$ & TN/TP \\
\hline \multicolumn{15}{|l|}{ Guadarrama } \\
\hline \multicolumn{15}{|l|}{ Mountains } \\
\hline Peñalara & 6.87 & 16 & 53 & 23 & 39 & 4 & 106 & 33 & 4 & 27 & 22 & 164 & 7 & 15 \\
\hline Claveles & 6.85 & 7.0 & 23 & 16 & 52 & 17 & 44 & 15 & 7 & 18 & 45 & 403 & 26 & 15 \\
\hline Pájaros & 6.80 & 23.1 & 27 & 13 & 44 & 8 & 120 & 37 & 17 & 11 & 321 & 529 & 35 & 15 \\
\hline \multicolumn{15}{|l|}{ Gredos } \\
\hline \multicolumn{15}{|l|}{ Mountains } \\
\hline Duque & 6.50 & 8.0 & 49 & 20 & 47 & 3 & 94 & 12 & 10 & 7 & 0 & 92 & 6 & 15 \\
\hline Cura & 5.89 & 18.4 & 56 & 21 & 80 & 21 & 120 & 14 & 33 & 145 & 84 & 848 & 13 & 65 \\
\hline Barco & 6.49 & 10.2 & 26 & 23 & 25 & 3 & 46 & 13 & 4 & 52 & 53 & 225 & 7 & 32 \\
\hline Cervunal & 5.52 & 14.4 & 33 & 22 & 47 & 15 & 79 & 2 & 18 & 245 & 284 & 1559 & 39 & 40 \\
\hline Majalaescoba & 7.00 & 7.8 & 29 & 16 & 24 & 2 & 42 & 14 & 6 & 125 & 29 & 256 & 5 & 51 \\
\hline Lagunilla & 6.23 & 9.3 & 33 & 9 & 18 & 2 & 66 & 16 & 7 & 12 & 105 & 355 & $<0.1$ & - \\
\hline Grande Gredos & 6.72 & 7.0 & 35 & 15 & 15 & 3 & 47 & 19 & 6 & 100 & 64 & 245 & 17 & 14 \\
\hline Nava & 6.60 & 6.6 & 13 & 6 & 20 & 2 & 34 & 10 & 5 & 9 & 118 & - - & 8 & -- \\
\hline Caballeros & 6.62 & 9.9 & 25 & 18 & 19 & 2 & 45 & 16 & 5 & 9 & 31 & - - & 12 & - - \\
\hline Trampal 3 & 6.24 & 9.5 & 51 & 23 & 44 & 5 & 103 & 20 & 10 & 2 & 0 & 98 & 3 & 33 \\
\hline Negra & 6.50 & 13.0 & 56 & 30 & 24 & 2 & 101 & 25 & 6 & 14 & 125 & 303 & 8 & 38 \\
\hline Cuadrada & 6.55 & 6.6 & 13 & 7 & 14 & 2 & 36 & 10 & 6 & 26 & 122 & 532 & 22 & 24 \\
\hline Gargantón & 6.18 & 8.1 & 23 & 9 & 15 & 2 & 33 & 11 & 5 & 0 & 101 & 313 & 9 & 35 \\
\hline Bajera & 7.24 & 5.3 & 20 & 13 & 13 & 3 & 36 & 10 & 5 & 8 & 75 & 227 & 24 & 9 \\
\hline Brincalobitos & 6.90 & 5.5 & 18 & 13 & 11 & 2 & 29 & 11 & 5 & 62 & 29 & 204 & 23 & 9 \\
\hline Trampal 2 & 7.03 & 12.9 & 69 & 23 & 54 & 3 & 129 & 28 & 11 & 14 & 0 & 176 & 7 & 25 \\
\hline Trampal 1 & 6.40 & 17.7 & 114 & 62 & 62 & 4 & 167 & 34 & 12 & 34 & 0 & 514 & 10 & 51 \\
\hline Mediana & 7.15 & 5.2 & 21 & 11 & 12 & 1 & 30 & 11 & 6 & 14 & 1 & 167 & 9 & 19 \\
\hline Galana & 7.47 & 5.1 & 20 & 11 & 11 & 2 & 39 & 11 & 5 & 13 & 103 & 228 & 10 & 23 \\
\hline Cimera & 6.80 & 5.3 & 20 & 14 & 15 & 2 & 42 & 3 & 2 & 36 & 0 & 288 & 9 & 32 \\
\hline Trochagosta & 6.73 & 7.7 & 15 & 4 & 31 & 2 & 63 & 13 & 7 & 35 & 290 & 208 & 2 & 104 \\
\hline Gutre & 6.52 & 9.3 & 24 & 13 & 20 & 3 & 33 & 13 & 8 & 159 & 56 & 252 & 14 & 18 \\
\hline
\end{tabular}




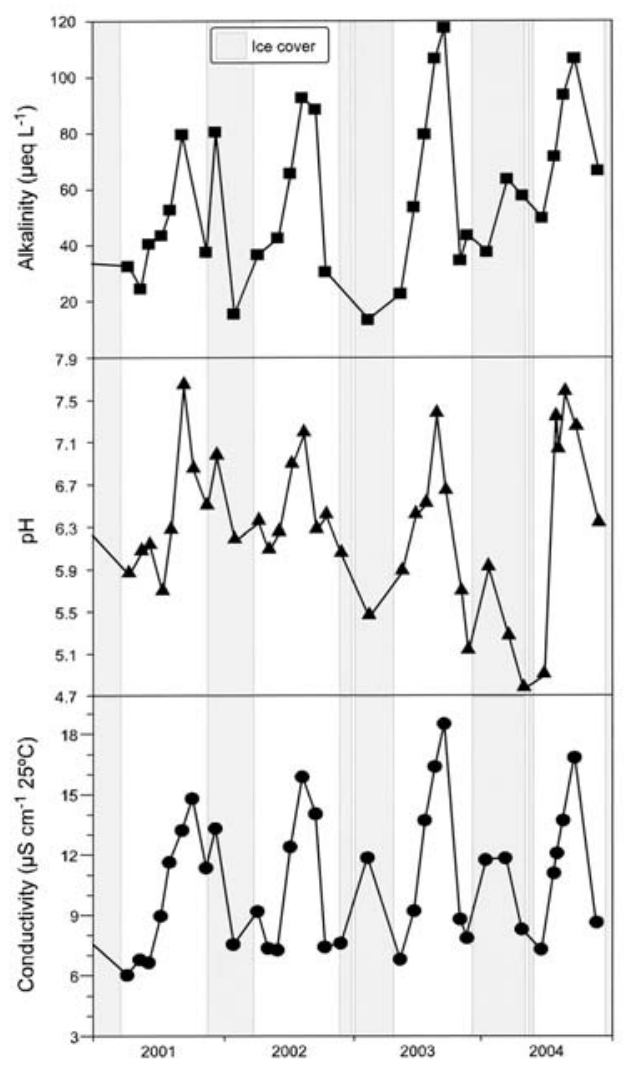

Figure 10. Seasonal variation of alkalinity, $\mathrm{pH}$ and conductivity in Peñalara Lake during a four years period (2001-2004). Variación estacional de la alcalinidad. pH y conductividad en la laguna de Peñalara durante un periodo de cuatro años (2001-2004).

2000-2001, when the ice cover was thinner and lasted less time, the increase in conductivity was small $\left(<9 \mu \mathrm{S} \mathrm{cm}^{-1} 25^{\circ} \mathrm{C}\right)$. The clear $\mathrm{pH}$ peaks in these deep layers is also only observed in the years with a long-lasting ice cover. When the ice is formed, there's ionic exclusion, as observed in other high mountain or alpine shallow lakes (Barica, 1977; Baron, 1992; Welch \& Bergman, 1985). The magnitude of this process can be approximately quantified with the example of the Peñalara Lake: with an ice cover of more than $1 \mathrm{~m}$ thick (1995-96 or 2003-04), it is assumed that more than $40 \%$ of the lake water volume becomes ice. There's also a release of basic cations from the sediment (Psenner, 1988) and a sulphate and nitrate reduction in the anoxic condition that can be reached in the few millimetres of the water-sediment interface (Psenner \& Catalan,
1994). The final result is a remarkable increase in the lake deeper layers conductivity, as well as an increment in the alkalinity -and therefore, of $\mathrm{pH}-$ of the water layer closer to the sediment. Under the ice, though, these parameters remain low. The more potent, stable and durable the ice cover, the more intense these changes in the lake water chemistry are. During the ice cover melting, there is a water mineralization increment due to the early fusion of the ion richer layers; nevertheless, the most important result is the input of a large quantity of water in the lake, which has a dilution effect in the medium, reaching the annual minimum conductivity, with extremely low values. The $\mathrm{pH}$ and alkalinity also decrease, with the input of acid ions retained in the snowpack and ice cover (Fig. 10). In the Cimera Lake, there has been a conductivity measurement of $1.34 \mu \mathrm{S} \mathrm{cm}^{-1}$ $25^{\circ} \mathrm{C}(7 / 7 / 98)$, which is assumed to be the lowest registered value in these high mountain lakes. Therefore, the conductivity seems to be a good indicator of the intensity of the processes present in a lake as a consequence of the ice cover formation, such as the ion and compound fluxes from the sediment, the oxygen depletion in the bottom or the generation of alkalinity.

The wide $\mathrm{pH}$ range observed in some lakes (Peñalara) (Fig. 10) is due to the scarce alkaline reserves (bicarbonate) which characterizes their hydrochemistry, in essence, the low buffering capacity of the water. Thus, their sensitivity to the atmospheric input of acid anions is very high, and acid rain is one of the potential risks for this type of lakes. There have been records of dry or wet deposition of dust from the Sahara (e.g. the orange snow episode in the Peñalara Lake in the winter of 1992), which contribute for the neutralization of the possible acid compound inputs from atmospheric deposition. This dust from the Sahara is an important source of alkalinity and nutrients for the alpine lakes in southern Europe (Psenner 1999), contributing with a high percentage of the total annual calcium $(70 \%)$ and bicarbonate (100\%) input in the lake watersheds (Rogora et al., 2004). Nevertheless, in the absence of this dust deposition from the Sahara, the snow is usually highly acid ( $\mathrm{pH}$ between 4.19 and 5.43), with an extremely variable ionic composition, influencing in the lake 
hydrochemistry, especially during the ice cover melting period. Even though the bicarbonate concentration is low $\left(<100 \mu \mathrm{eq} \mathrm{L} \mathrm{L}^{-1}\right)$, they represent a high percentage of the ionic composition in these lakes, reaching values of close to $90 \%$ of the total anions in lakes like the Cimera, one of the least mineralized in all of the Central Range. The predominance of sulphates over chlorides reflects the distance from the ocean -and thus, from the influence of marine aerosols. The following relations are found in the Central Range lakes: for cations $\left[\mathrm{Ca}^{2+}\right] \geqslant\left[\mathrm{Na}^{+}\right]>\left[\mathrm{Mg}^{2+}\right]>>\left[\mathrm{K}^{+}\right]$, and for anions $\left[\mathrm{HCO}_{3}{ }^{-}\right] \geqslant\left[\mathrm{SO}_{4}{ }^{-}\right]>\left[\mathrm{Cl}^{-}\right]$. These relations are common in high mountain lakes on silica basins in other continental mountainous systems in the world (Baron, 1992; MOLAR, 1999). Summarizing the chemical composition described above, the water in most of the Central Range lakes can be classified as a mix between bicarbonate-calcic and bicarbonate-sodic, a result of the crystalline lithology of the basins (gneisses and granites).

Nitrate concentration is low in most of studied lakes $\left(<60 \mu \mathrm{g} \mathrm{L}^{-1} \mathrm{~N}-\mathrm{NO}_{3}\right)$, with the exception of Cura, Cervunal, Majalaescoba, Grande de Gredos or Peñalara lakes, where $\mathrm{NO}_{3}$ reached higher values. Ammonium concentration is usually under $90 \mu \mathrm{g} \mathrm{L}^{-1} \mathrm{~N}^{-\mathrm{NH}_{4}}$, and mean annual values are about $20 \mu \mathrm{g} \mathrm{L}^{-1}$. Total phosphorus concentration do not exceed $25 \mu \mathrm{g} \mathrm{L}^{-1}$, except for Cervunal Lake, where a maximum of $39 \mu \mathrm{g} \mathrm{L}^{-1} \mathrm{P}$ was recorded. TN/TP ratio founded in summer months in lakes ranges from 9 to 104. Kopacek et al. (1996) established a TN/TP ratio of 7.2 for phytoplankton in high mountain

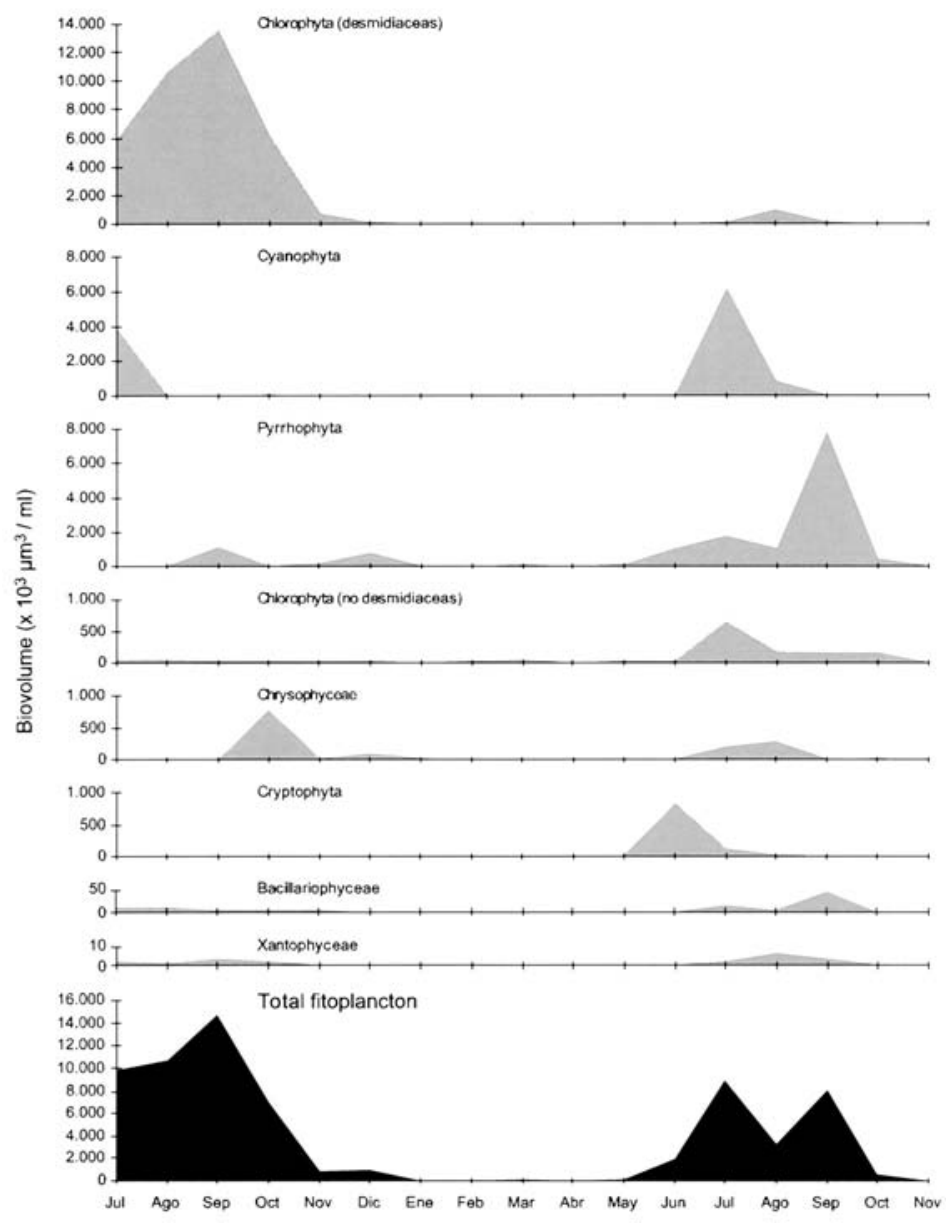

Figure 11. Annual succession pattern of the main phytoplankton groups in Peñalara Lake (Source: Toro \& Montes, 1993). Patrón de sucesión anual de los principales grupos del fitoplancton en la laguna de Peñalara (Fuente: Toro \& Montes, 1993). 
lakes; therefore, summer productivity should be P-limited in most of lakes. In Peñalara Lake, several years of monthly monitoring show a Plimited productivity during most all-year period, but TN/TP trend to reach lower values is detected in summer periods, changing to a N-limited phytoplankton productivity. This trend has been also observed by Morales-Baquero et al. (1999) in a survey of 31 high mountain lakes in Sierra Nevada (Southern Spain), where the importance of atmospheric $\mathrm{N}$ and $\mathrm{P}$ inputs together with the size of the lake catchment is highlighted.

\section{Phytoplancton}

The phytoplankton communities in the studied lakes are composed of widely distributed, nonendemic species, most of them typical of acidic oligotrophic lakes. Figure 11 reflects the annual succession pattern of the main algae groups in the Peñalara Lake (Toro \& Montes, 1993). In the summer, with water column stability and high nutrient content and temperatures, the main algae groups reach their maximum density and biovolume: chlorophytes (up to $90 \%$ of the biomass), with an alternation of predominance of Zygnematales (Arthrodesmus sp.) with Chlorococcales (Chlorella sp., Dydimocystis sp., Scenedesmus sp.), cianobacteria (summer bloom characteristic of a filamentous species, without heterocysts; Aphanothece sp., Pseudanabaena sp.) and, at the end of the summer, dinoflagellates and diatoms (Aulacoseira sp., Fragilaria sp.) favoured by the first autumn rains. The importance of planktonic diatoms is very low $(<1 \%)$ in the lakes studied, in comparison to their importance to the benthonic communities. The density of flagellate algae, favoured by their mobility in the stratification bellow the winter cover, increases in the beginning of the winter: dinoflagellates (Amphidinium sp., up to $50 \%$ of the biomass), chrysophytes (Dynobrion sp., Ochromonas sp.) and some flagellate chlorophytes (Pedinomonas sp.). The ice cover melting causes a low phytoplankton density, even though small flagellate groups persist. This community succession annual pattern happens in the group level, since each period's dominant species usually vary each year (Toro y Granados, 1997). There is a strong correlation between the different phytoplankton communities and the lake's degree of mineralization, indicating a low organic contamination, or by nutrients in general, since this is the main factor that differentiates the algae communities (De Hoyos \& Negro, 2001). The smaller and shallower lakes have been found to be the richest in number of species (e.g.: $>200$ species in the Peñalara Lake) (Toro \& Montes, 1993; De Hoyos \& Negro, 2001), in which the proportion of benthonic or shore habitats exceeds the pelagic zone, not corresponding to typically planktonic communities $(>30 \%$ of the algae species are diatoms, and most are benthonic).

\section{Macrophytes}

The composition of the macrophyte communities is determined by the degree of temporality or water level fluctuation in the lakes, and there are two main communities: permanent lakes with stable water level or shallow lakes or ponds with a fluctuating water level (Aldasoro \& Toro, 2001). The typical alpine aquatic systems species are in the first group: Subularia acuatica, Isoetes velatum, Callitriche palustris or Sparganium angustifolium are the most representative. Subularia acuática, a boreoalpine species, has in the Trampal 1 and 2 lakes their only known distribution in the Central Range (Aldasoro \& Toro, 2001). The surface area covered and the richness depend on the morphology of the shore and on the substrate type. Therefore, the Grande de Gredos Lake, with a large shore development and shallow zones, has one of the largest macrophyte richness and density in the Central Range. The most characteristic species of the second group are Ranunculus peltatus, Antinoria agrostidea, Potamogeton natans or Juncus bulbosus. Bryophyte species of the Fontinalis and Sphagnum genera are also common in the lakes. In the Guadarrama Mountains, the Grande de Peñalara Lake does not have any aquatic vegetation, although a couple of Callitriche plants were observed by the lake shore in 2002-2003 summer periods. 
Nevertheless, there is in the area a total of 27 aquatic plant species (angiosperm phanerogams, charophytes and bryophytes), with the presence of Nitella flexilis, a charophyte typical of oligotrophic waters (Granados \& Toro, 2000b).

\section{Zooplankton}

The zooplankton species richness in the lakes studied is smaller than in other alpine systems in the northern Iberian Peninsula (Miracle, 1978; Vega et al., 1991), being more like other lakes in the southern Peninsula (Cruz-Pizarro et al., 1981). There have been found 21 species in the Gredos Mountains lakes (Robles \& Aldasoro, 2001), similar to the 19 species found in the Guadarrama Mountains lakes (Toro \& Granados, 1998). Both mountain systems present a very similar community composition, with low specialized and cosmopolitan, copepods and cladoceran species, such as Tropocyclops prasinus, Ceriodaphnia quadrangula, Daphnia longispina or Chidorus sphaericus. Nevertheless, there are species with a more boreoalpine character, such as Alonella nana. The main difference between these mountain systems is the absence of the diaptomid Diaptomus castaneti in the Peñalara lakes, with presence in the Gredos lakes and in other mountain systems of the northern Iberian Peninsula (Aldasoro et al., 1984). The most frequent diaptomid in the Pyrenees lakes, Diaptomus cyaneus (Miracle, 1978), is not present in the Peñalara lakes, but has been cited in some high mountain ponds in an area very close to the Peñalara Massif (Baltanas, 1985). Within the rotifer group, species such as Poliarthra remata and Asplachna priodonta dominate in the summer months, while Keratella quadrata dominate in the winter, in the absence of predatory pressure from Asplachna sp. (Toro \& Granados, 1997).

\section{Macroinvertebrates}

The richness of species in the benthonic macroinvertebrate communities is high in the Central Range lakes. More than 90 species have been identified in the Gredos Mountains, with 47 belonging to the chironomid group, with 33 different genera
(Toro \& Granados, 2001). A total of 59 species have been identified in the Guadarrama Mountains lakes, with 29 chironomids (Granados \& Toro, 2000b). This is one of the groups that contribute the most to the total benthonic invertebrate biomass in these lakes with mean values of 847 individuals $/ \mathrm{m}^{2}$ for the Peñalara Lake, and peak concentrations of almost 4000 individuals $/ \mathrm{m}^{2}$. The species Micropsectra spp., Heterotrissocladius marcidus or Parakieffieriella bathphyla, frequent in alpine systems (Langton, 1991; Rossaro, 1982; Soriano, 1995), stand out for their abundance. The oligochaetes are another group that represent a large proportion of the benthonic biomass in several of the lakes. The two most characteristic species are Stylodrilus heringianus, typical of oligotrophic environments, and Nais alpina, characteristic of high mountains (Brinkhurst, 1971). The mean abundance of individuals in the Peñalara Lake is 317 individuals $\mathrm{m}^{-2}$, with maximum abundance of up to 1800 individuos $\mathrm{m}^{-2}$. Besides the chironomids and oligochaetes, species like Sialis lutaria, a megalopteran predator, and Pisidium casertanum, the only represented bivalve mollusc, are common in the silty substrate of the lake bottom, with densities between 38 and 150 individuals $/ \mathrm{m}^{2}$ in the Peñalara Lake. In the lake shores, where there's greater substrate diversity, there are also other gastropod (Ancylus fluviatilis), hirudinea (Helobdella stagnalis), ephemeroptera (Baetis fuscatus, Siphlonurus lacustris, Habrophlebia fusca), plecoptera (Protonemura meyeri), tricoptera (Plectrocnemia conspersa, Athripsodes cinereus), odonata (Selysiothemis nigra), coleoptera (Nebrioporus fabressei, Oulimnius tuberculatus) and heteroptera (Notonecta obliqua, Arctocorisa carinata, Sigara sp.) (Granados \& Toro, 2000b). The distribution of some species can be a response to certain impacts suffered by some lakes. Helobdella stagnalis, a species that tolerates anaerobic conditions or temporary dry periods, indicating an organic matter enrichment (Elliot \& Mann, 1979), is present only in lakes that have been altered by damming (Barco, Trampal 3), with abundant aquatic vegetation (Grande de Gredos, Trampal 1) or with incipient eutrophication processes from a recent past (Peñalara and Grande de Gredos). The trichoptera are absent in the dammed 
lakes, and from the lakes with a superior trophic level (Cura, Negra and Cervunal). The formation of a dry section in the shores of the dammed lakes, due to the water level oscillation, can hinder the colonization of the shore area by some macroinvertebrate groups. There are Chironomus sp. in some well conserved lakes, characteristic of situations with intense organic matter decomposition in usually eutrophic environments. This is explained by its adaptation to oxygen depletion in the bottom during the formation of the ice cover in the winter. Larger sized species from the odonata, coleoptera or heteroptera families are only present in the Central Range lakes without fish or with abundant aquatic vegetation.

\section{Vertebrates}

There are several fish, amphibious, reptile and mammal species in the Central Range lakes. Among the fish, the only endemic Iberian species is the brown trout (Salmo trutta), present in only 6 lakes, although it hasn't been confirmed if this presence is natural or has been introduced. Besides that, the brook trout (Salvelinus fontinalis) has been introduced in the Cinco Lagunas complex (Cimera, Galana, Mediana, Brincalobitos and Bajera) and in the Peñalara Lake, and the Iberian chub (Leuciscus carolitertii) and the Iberian nase (Chondrostoma polylepis) have been introduced in the Duque Lake (Lizana \& Morales, 2001).

In the Gredos and Guadarrama Mountains lakes and wetlands, there are 10 amphibious species: the common salamander (Salamandra salamandra), the alpine newt (Triturus alpestris) (introduced in Peñalara in the beginning of the 1980s), the marbled newt (T. marmoratus), the midwife toad (Alytes obstetricans), the natterjack toad (Bufo calamita), the common toad (B. bufo), the Portugal painted frog (Discoglossus galganoi), the San Antonio frog (Hyla arborea), the Iberian frog (Rana iberica) and the green frog (R. perezi) (Lizana \& Morales, 2001; Martínez-Solano et al., 2002). Among the reptiles, there are only two species related to the aquatic ecosystems of these mountains: the two snakes of the genus Natrix (N. natrix and N. maura) (Lizana \& Morales,
2001). Finally, among the mammals, the otter (Lutra lutra) and the American mink (Mustela vison) are occasional visitors to the lakes searching mainly for fish, and occasionally for amphibious and other preys. The mink is an introduced species, naturalized in the Central Range by escaping the farms where it is raised for its fur. The Iberian desman (Galemys pyrenaica), although a fluvial habitat species, is occasionally present at some Gredos lakes (Lizana \& Morales, 2001).

\section{ENVIRONMENTAL CHANGE AND THE IMPACT IN THE CENTRAL RANGE HIGH MOUNTAIN LAKES}

\section{Incipient eutrophication of the Peñalara Lake caused by tourism and cattle}

In the end of the 1980s, the Peñalara Lake presented symptoms during the summer period that indi-
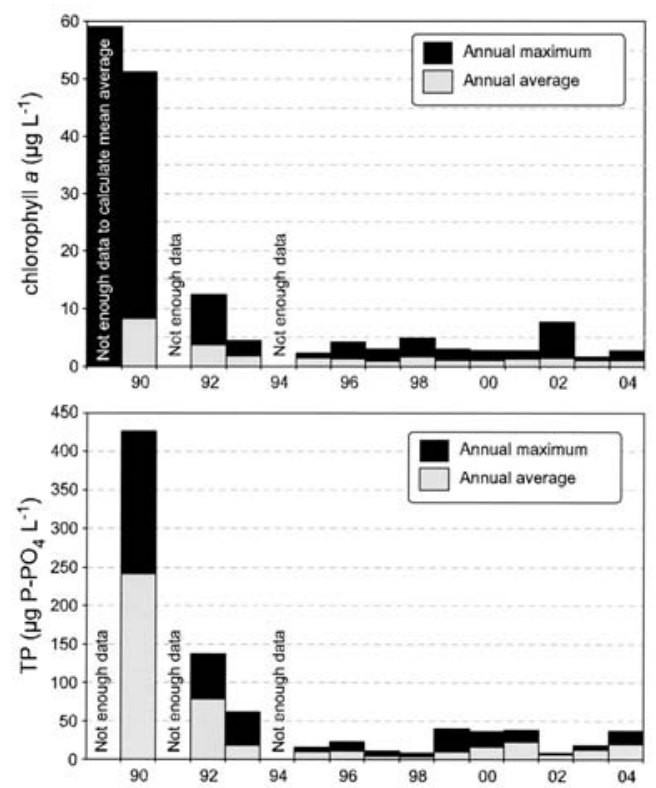

Figure 12. Chlorophyll $a\left(\mu \mathrm{g} \mathrm{L}^{-1}\right)$ and TP $\left(\mu \mathrm{g} \mathrm{P}-\mathrm{PO}_{4} \mathrm{~L}^{-1}\right)$ evolution in Peñalara Lake during a 15 years period. Recovery of natural levels of both variables, after restoration measures were adopted to reduce the input of nutrients (1991-1993), is observed. Evolución de la clorofila a $\left(\mu g L^{-1}\right)$ y TP $\left(\mu g P_{-} P_{4} L^{-1}\right)$ en la laguna de Peñalara durante un periodo de 15 años. Se observa la recuperación de los niveles naturales de ambas variables despues de que se adoptasen medidas de restauración para reducir la entrada de nutrientes (1991-1993). 
cated an increase in the phytoplankton and benthic primary production. Chl-a concentration over $50 \mu \mathrm{g} \mathrm{L}{ }^{-1}$ was recorded in the August 1990, in waters of an intense green and Secchi disk transparency under $50 \mathrm{~cm}$. The maximum phosphorous concentration during that month was $427 \mu \mathrm{g}$ P$\mathrm{PO}_{4} \mathrm{~L}^{-1}$, with a mean annual value of $242 \mu \mathrm{g}$ P$\mathrm{PO}_{4} \mathrm{~L}^{-1}$. Several management practices were adopted in 1991 in order to reduce the nutrient input from human activity in the lake watershed: bathing and camping were prohibited, and cattle access to the lake was limited. The chlorophyll concentration decreased in a short period, approaching oligotrophic levels (Fig. 12), with summer maximums of $12.4 \mu \mathrm{g} \mathrm{L}^{-1}$ in 1992 and $4.5 \mu \mathrm{g} \mathrm{L}^{-1}$ in 1993, and phosphorus values of $137 \mu \mathrm{g} \mathrm{P}^{-\mathrm{PO}_{4} \mathrm{~L}^{-1}}$ in 1992 and 62 in 1993. From 1995 on, there was a clear annual pattern of this variable, with a Chl-a summer peak concentration of between 3-8 $\mu \mathrm{g} \mathrm{L}^{-1}$, and phosphorus peaks of $10-40 \mu \mathrm{g} \mathrm{P}^{-\mathrm{PO}_{4}} \mathrm{~L}^{-1}$. Chl-a reached $7.6 \mu \mathrm{g} \mathrm{L}^{-1}$, in the summer of 2002 , coinciding with a previous winter with very low rain and snow precipitation - which caused the lake turnover rate to be smaller and the water level to be the lowest. Chlorophyll concentration is minimum in the ice cover period, with mean minimum values under $1 \mu \mathrm{g} \mathrm{L}^{-1} \mathrm{Chl}-\mathrm{a}$, although higher maximums under the ice cover have been recorded in some years. In the winter of 2004-2005, for example, there was a remarkable chlorophyll increment in the deeper layers close to the sediment, reaching values of $7.7 \mu \mathrm{g} \mathrm{L}^{-1}$, and $0.4 \mu \mathrm{g} \mathrm{L}^{-1}$ in the layers adjacent to ice cover. The sensitivity of the phytoplankton primary production in the high mountain lakes to environmental variables such as total annual or winter precipitation, temperature or nutrient input, is evident in the response obtained throughout the management practices adopted in the Peñalara Lake to control nutrient input related to visitors and cattle. The turnover rate of some lakes (mean annual values of under 15 days, with minimum values of under 1 day during the melting of the ice cover) favour the fast recover of the oligotrophic levels, by producing a decrease in the nutrient input, reaching natural levels in 2 or 3 years of control. The high sensitivity of these ecosystems with oligotrophic vocation is demonstrated by the increments in summer maximum concentration of chlorophyll related to the minimum values of winter precipitation, which generate a lower melting volume, and thus, a lower turnover rate.

\section{Wastewater inflow from a refuge in the Grande de Gredos Lake}

In 1971 a mountain refuge was built close to the inlet stream of the Grande de Gredos Lake, near its south basin (Fig. 4). Until 1995, the residual waters were depurated in a waste treatment lagoon in a natural pond located between the refuge

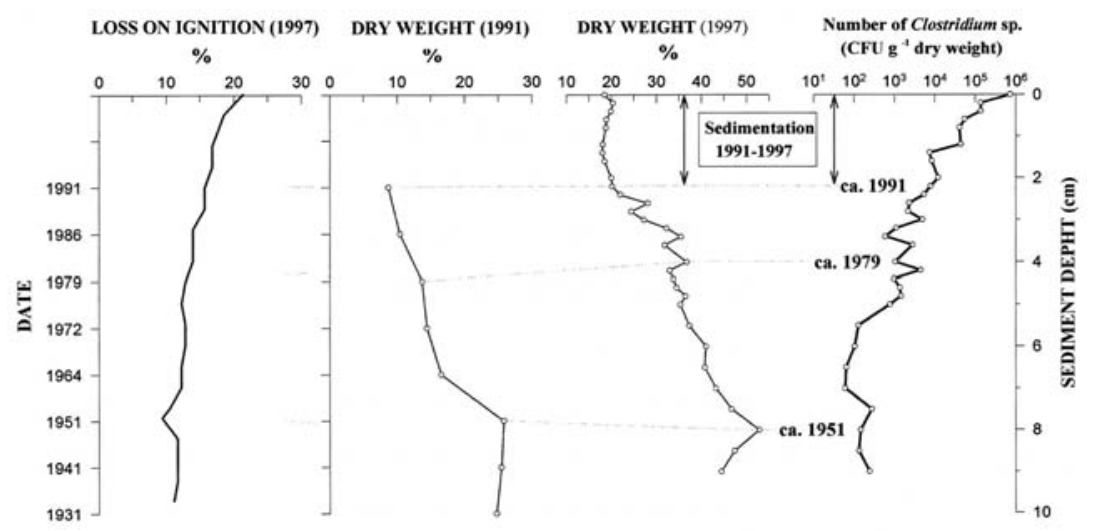

Figure 13. Dry weight (\%), organic matter (\% loss on ignition) and number of Clostridium sp. (CFU/g: colony-forming units per gram of dry weight of sediment) profiles of sediment cores collected at Grande de Gredos Lake in 1991 and $1997 .{ }^{210} \mathrm{~Pb}$ dating was carried out for 1991 sediment core (adapted from Toro et al., 1993 and Robles et al., 2000). Perfiles de peso seco (\%), materia orgánica (\% pérdida por combustión) y número de Clostridium $s p$. (CFU/g: unidades de colonias formadas por gramo de peso seco de sedimento) en dos testigos de sedimento obtenidos en la laguna Grande de Gredos en 1991 y 1997 . El perfil de 1991 fue datado con ${ }^{210} \mathrm{~Pb}$ (adaptado de Toro et al., 1993 y Robles et al., 2000). 

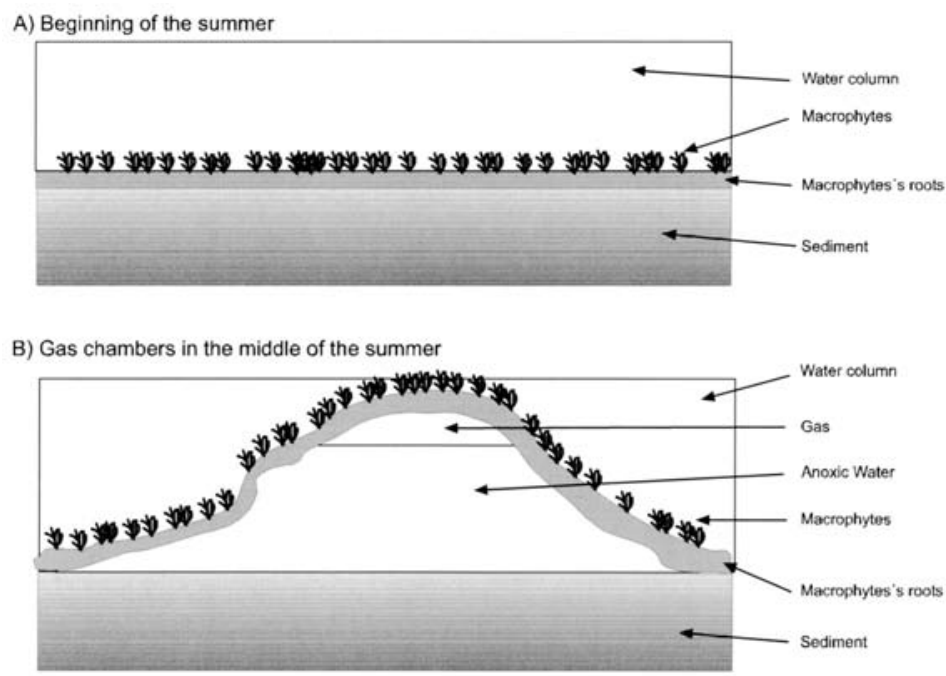

Figure 14. Formation process of the gas chambers and anoxic water layer under macrophyte roots in the bottom of south basin at Grande de Gredos Lake as a consequence of a waste water inflow from a refuge (Summer 1995). Proceso de formación de cámaras de gas y capas de agua anóxica bajo las raices de las macrófitas en el fondo de la cubeta sur de la laguna Grande de Gredos como consecuencia del vertido de un refugio (verano de 1995).

and the lake. In that year, a more complex depuration system was constructed. It consisted basically of an initial grid, a $1^{\text {st }}$ decant-anaerobic digestion tank, and a $2^{\text {nd }}$ aerobic digestion tank with an electric air diffuser. The resultant effluent or wastewater circulated through some drainage pipes surrounded by gravel and sand in a ditch towards the Grande de Gredos Lake. During the following winter, one depuration system tank broke, due to the ice and the weight of the snow mantle over the installation, generating a continuous flow of wastewater into the lake. At the same time, the faulty operation has not produced the desirable purification levels. In this way, a second source of scarcely purified wastewater with diffuse character, passed through the drainage pipes, because the depuration system did not work due to low winter temperatures and to the lack of power. Tank repairs during the next summer originated a wastewater spill of about 6000 litres of black waters without depuration treatment over the surrounding area, close to the lake. This fact, together with diffuse pollution caused by the high number of visitors and campers in the lake watershed, originated serious changes in the lake's trophic level.

The paleolimnological surveys carried out in 1991 and 1997 reflected a big increase in the organic matter content accumulated in the period between both studies, as well as an increase in the sedimentation rate. A general trend to increase the organic matter content (measured as LOI) since the beginning of the 1960's, according to the ${ }^{210} \mathrm{~Pb}$ dating, is observed along the sediment record (Fig. 13). Before 1991, the sedimentation rate was around $2.2 \mathrm{~mm} /$ year, increasing after that year to reach values of approximately $5 \mathrm{~mm}$ /year. This increase clearly reflects an extraordinary input of organic matter (measured by LOI) in the past few years. Since the lake has two different basins (Fig. 4), comparisons between north and south basins sediment profiles were made to look for differences in the sedimentation rates and organic matter content. The input of soluble and particulate materials (of natural origin from the watershed drainage or from the refuge and campground area) is higher in the south basin, which acts as a sediment and nutrient trap prior to the north basin. The LOI concentration in the surface sediment of the south basin is much higher than in the north basin, although there is an acceptable correlation between both curves' trends.

One of the main impacts and extreme consequences in the lake ecosystem because the high organic matter input from the refuge was the for- 
mation of gas chambers, under macrophyte roots in the south basin. These gases originate as a consequence of intense organic matter degradation in anaerobic conditions. In another lake of the Central Range, the Trampal 3, a similar process has been verified as a consequence of the modification of the hydrological cycle due to damming lake (Toro \& Granados, 2001). The formation of bacterial mats in the upper layers of the sediment, together with the dense net of macrophyte roots, hinders the efflux of the gas to the atmosphere. Because of this accumulation, the macrophytes and their roots are lifted up towards the water surface. In this way, gas chambers and a layer of anoxic water with relatively high concentrations of nutrients $\left(\left[\mathrm{P}-\mathrm{PO}_{4}{ }^{=}\right]=43\right.$ $\left.\mu \mathrm{g} \mathrm{L}^{-1},\left[\mathrm{NH}_{4}^{+}\right]=1.025 \mathrm{mg} \mathrm{L}^{-1}\right)$, reach a height of $2 \mathrm{~m}$ and a surface area of several square metres. The formation process of the gas chambers and anoxic water layer is schematised in figure 14 .

Robles et al. (2000) studied the effects of outdoor activities in the Grande de Gredos Lake watershed by the analysis of sulphite-reducing clostridia in the lake sediment from the south basin. Sulphite-reducing clostridia are good indicators of past human pollution because of their longevity in natural habitats, and they cannot multiply at temperatures below $20^{\circ} \mathrm{C}$, or in the presence of $\mathrm{O}_{2}$. There was a great increase in the numbers of clostridia (expressed as colonyforming units per gram (CFU $\mathrm{g}^{-1}$ ) of dry weight of sediment) in the sediment record of this lake since the 1970s, showing the rise of human pressure caused by the practice of outdoor activities. Clostridia CFU g-1 increased dramatically after the breakdown of the refuge's depuration system in 1995 (Fig. 13). Concentration levels of clostridia in the north basin of this lake were similar to those found in the surface sediment of the Cimera Lake, located in a more remote area without this high tourist pressure: both were two orders of magnitude lower than in the Grande de Gredos Lake (Robles et al., 2000).

Additional evidences of a recent nutrient and organic content enrichment in the lake has been provided by Toro et al. (1993) by means of the subfossil diatoms analysis from the sediment core taken in the north lake basin. It reflected a remarkable trend towards an increase in lake trophic conditions since the end of 60's. Some species, such as Navicula radiosa var. tenella, Pinnularia microstauron, Fragilaria pinnata or Aulacoseira sp., showed a response to a possible nutrient enrichment increasing their densities in more recent sediment layers, whereas other species associated to oligotrophic conditions, such as Achnanthes austriaca or Cymbella perpusilla, decreased their densities towards surface layers (Toro et al., 1993).

The progressive recovery that has been observed in the Grande de Gredos Lake after the repair and control of the wastewater inflow is another proof of the great self-recovery capacity which seems to be characteristic of these alpine systems. Nevertheless, the studies being carried on the follow up of these lakes biological communities (phytoplankton, zooplankton, macroinvertebrate and macrophytes) will provide knowledge in the future about the long term effects of these impacts.

\section{Erosion processes in the Peñalara Lake watershed}

The intense tourism and cattle raising activities in the proximity of the Peñalara Lake caused an advanced erosion process at the shores of the lake basin, in the beginning of the 1990s. The results obtained in the paleolimnological sediment study (Fig. 15) show clearly some of the effects of this pressure (Toro \& Granados, 2002). Firstly, the dispersed and irregular radiometric profile obtained from sediment dating shows a possible recent alteration in the surface sediment layers $(0-20 \mathrm{~cm})$, probably due to its re-suspension by the numerous bathers who visited the lake during the summer, as well as by livestock. A period of increased sediment accumulation is observed from the 1970's onwards, associated with denser sediment at a depth of $8.5 \mathrm{~cm}$ in the core. Furthermore, this period is the inflexion point of the relationship between the sedimentation rate (measured as $\mathrm{g} \mathrm{m}^{-2} \mathrm{y}^{-1}$ or $\mathrm{cm} \mathrm{y}^{-1}$ ) and annual precipitation. Figure $15 \mathrm{~b}$ shows that prior to 1970 , the sedimentation rate is inversely correlated to annual precipitation, but after that 

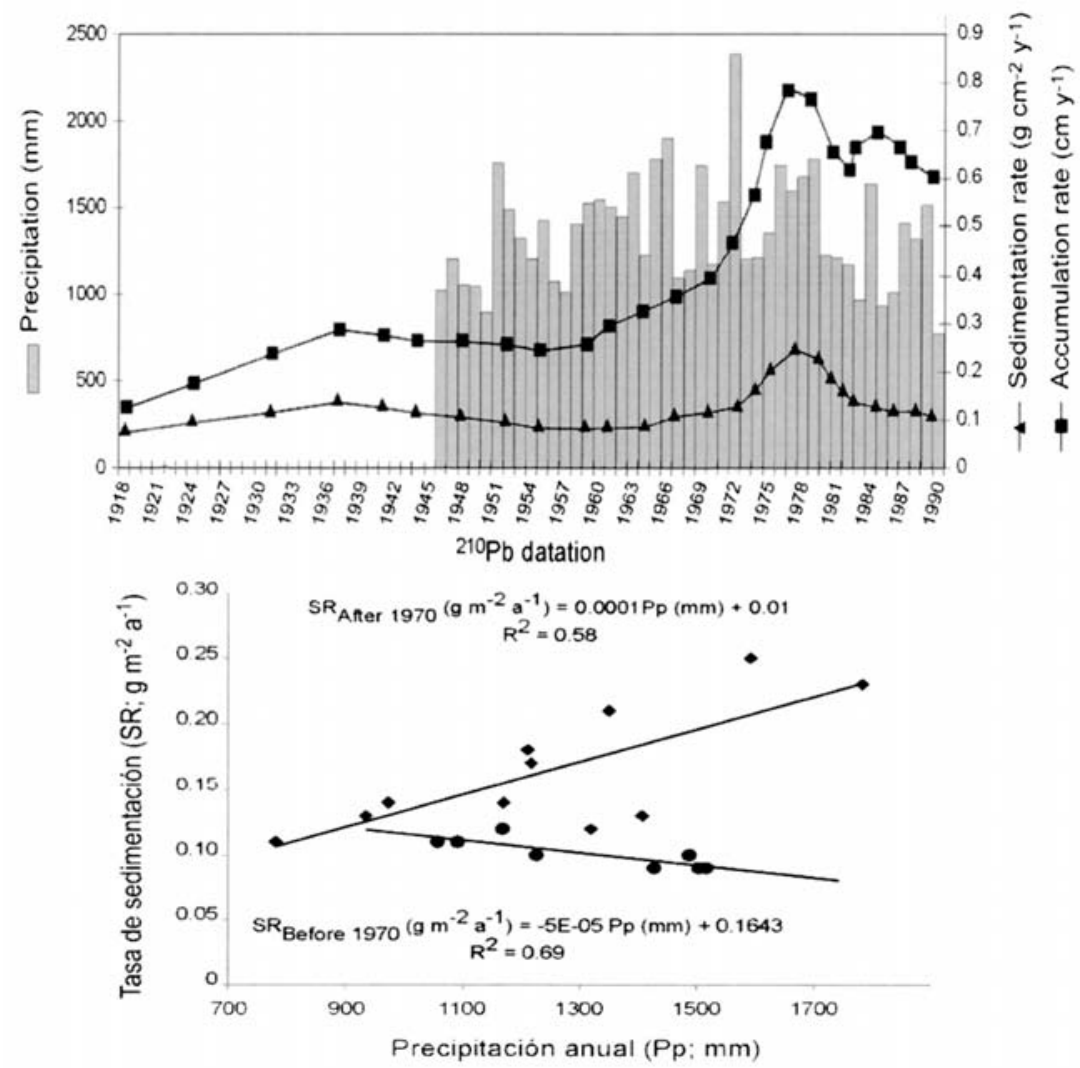

Figure 15. Relationship between sedimentation rate evolution and annual precipitation in Peñalara Lake during second half of $20^{\text {th }}$ century. Correlation changes between both variables prior and post 1970 is emphasized (Toro \& Granados, 2002). Relación entre la evolución de la tasa de sedimentación y la precipitación anual en la laguna de Peñalara durante la segunda mitad del siglo XX. Se señala el cambio producido en la correlación entre ambas variables antes y después de 1970 (Toro \& Granados, 2002).

year, a significant positive correlation is initiated between precipitation and sediment accumulation rate. Thus, before 1970, the sedimentation process was driven mainly by the opposed influence between the sedimentation and flushing rates: as water turnover time is reduced (i.e. more precipitation), the sedimentation rate is also reduced (Fig. 16). On the other hand, after 1970, a notable rise in the erosion rate in the watershed and at the shore of the lake starts as a consequence of the loss of vegetation cover (mainly mountain pasture) caused by visitors' trampling. Because of these large areas of bare soil, erosion increases with increased precipitation. In addition, at the shoreline and in shallow parts of the lake, bathing visitors cause a process of re-suspension of the sediment, which accumulates in the deeper area. Prior to the increase in organic content, at a depth of $8-10 \mathrm{~cm}$ there is a sharp drop in these values, coinciding with an increase in the percentage of dry weight and wet density, and less ${ }^{137} \mathrm{Cs}$ and ${ }^{210} \mathrm{~Pb}$ activity (Toro \& Montes, 1993). This may represent a strong erosion process in the watershed or at the shore of the lake, as has been previously discussed. In some areas of critical erosion level, soil losses up to almost $1 \mathrm{~m}$ of thickness were recorded between 1985 and 1995 (Toro and Granados, 1999). For some zones of the frontal moraine that encloses the lake, this loss meant almost half of the height of the same above the water level of the lake. After the prohibition of access to the lake, the vegetation cover was recovered in the least degraded zones, but the erosive process continued in the critical zones. In 1997, it was necessary to interfere, artificially seeding the soil with various species of grasses and protecting it with vegetable fibre matting. 


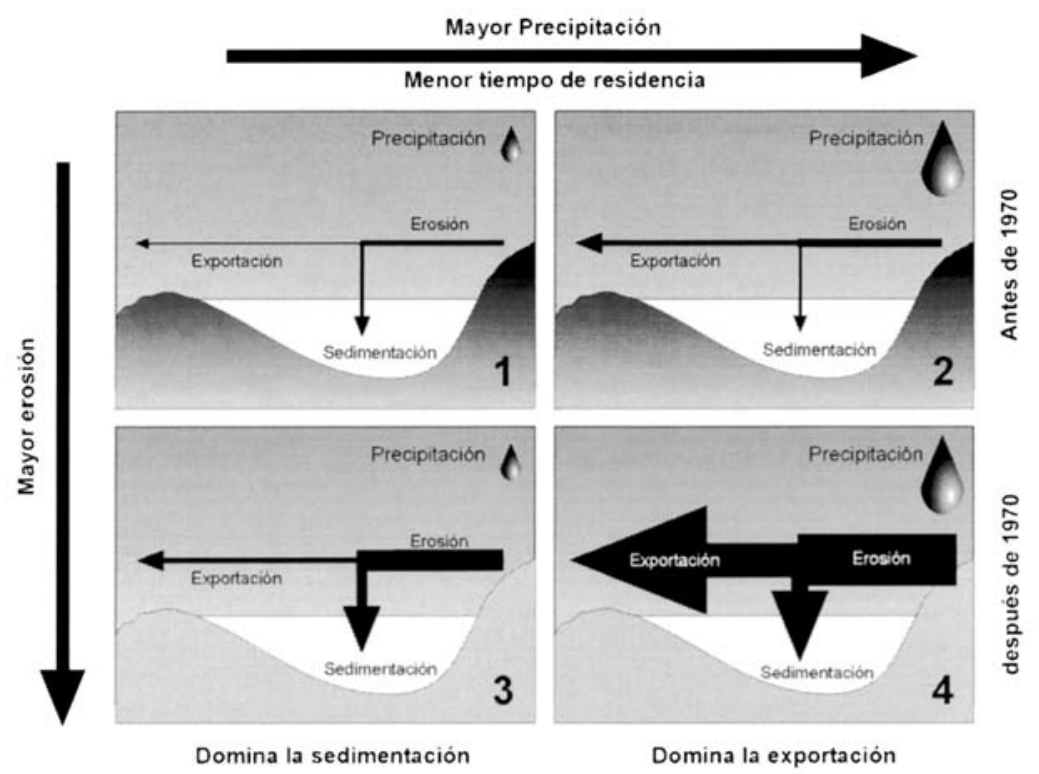

Figure 16. Annual model of the erosion-sedimentation processes in the watershed of a small high mountain lake in natural conditions (prior 1970) and with high soil erosion problems (post 1970): Peñalara lake (Granados et al., 2002). Modelo anual del proceso de erosión-sedimentación en la cuenca de un pequeño lago de alta montaña en condiciones naturales (antes de 1970) y con problemas de alta erosión del suelo (después de 1970): laguna de Peñalara (Granados et al., 2002).

The sedimentation rate in a lake basin may be used as an indirect measurement of sediment influx, i.e. the rate of erosion in the watershed (Dearing, 1986). The natural sedimentation processes in the studied lake watersheds follow a general annual pattern according to the erosion process degree (Fig. 16) (Granados et al., 2002). The sedimentation under the winter ice cover is minimal, without watershed material inflow and with a negligible photosynthetic primary productivity. During the melting period, the sedimentation rate is still low, due to the high lake water turnover rates, in spite of the very high available energy for particle transportation form the watershed (erosion) and the maximum soil erodibility due to its higher water content and the winter cryofraction phenomenon. During the summer, sedimentation reaches the annual maximum values, because of the higher water column stability, more visitors (watershed erosion) and annual maximum primary productivity (organic matter generation through photosynthesis), besides the highly erosive summer storms. The persistent autumn rains cause an increase in the turnover rates, a decrease in the primary productivity and, therefore, a decrease in the sedimentation rates.

To monitoring the response of erosion-sedimentation processes to the restoration measures adopted in the Peñalara Lake watershed, two sediment traps were located in the deepest area of the lake (1.3 and $2.6 \mathrm{~m}$ above lake bottom) in 1997. The annual evolution of the rate of organic/inorganic material caught in the sediment traps from 1997 to 2005 validates this model, since the largest percentage of inorganic material is observed in the summer (Fig. 17). In this period, the mineral material input by watershed erosion is higher, increasing the percentage of organic matter during the rest of the year (Granados et al., 2002). Besides this clear annual pattern, the sedimentation rates have varied in the last few years, with a trend of decreased sedimentation, due to the watershed erosion control measures adopted and the re-vegetation of the most affected zones (Toro $\&$ Granados, 2002). The sedimentation rates in the summer of 1997 were between 24.3 and $29.2 \mathrm{~g} \mathrm{~m}^{-2} \mathrm{~d}^{-1}\left(1.9 \mathrm{~kg} \mathrm{~m}^{-2} \mathrm{y}^{-1}\right)$, reached a maximum of only $10.9 \mathrm{~g} \mathrm{~m}^{-2} \mathrm{~d}^{-1}\left(0.83 \mathrm{~kg} \mathrm{~m}^{-2} \mathrm{y}^{-1}\right)$ in 1998, and have since reached annual maximum 


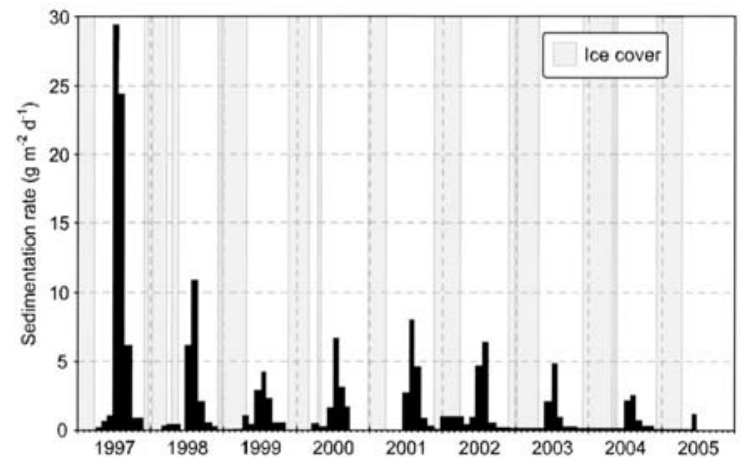

Figure 17. Interannual evolution of the sedimentation rate in Peñalara Lake according to the material collected in the sediment traps during the period 1997-2005. Evolución interanual de la tasa de sedimentación en la laguna de Peñalara según el material recogido en las trampas de sedimento durante el periodo 1997-2005.

values of between 2.6 and $8 \mathrm{~g} \mathrm{~m}^{-2} \mathrm{~d}^{-1}(0.22-$ $0.56 \mathrm{~m}^{-2} \mathrm{y}^{-1}$ ) (Fig. 17). According to the data obtained in the Peñalara Lake paleolimnological study (Toro and Montes, 1993; Granados et al., 2002), there was an annual maximum accumulation of $1.4 \mathrm{~kg} \mathrm{~m}^{-2} \mathrm{y}^{-1}$ between 1918 and 1970 , with a mean of $1.06 \mathrm{~kg} \mathrm{~m}^{-2} \mathrm{y}^{-1}$ for this period. From 1970 on, with the beginning of tourism related erosion processes, the maximum accumulation was $2.5 \mathrm{~kg} \mathrm{~m}^{-2} \mathrm{y}^{-1}$, with 1970-1991 mean of $1.59 \mathrm{~kg} \mathrm{~m}^{-2} \mathrm{y}^{-1}$. Therefore, it is shown that both the paleolimnological and the sediment trap techniques provide results of the same order of magnitude. However, when comparing the results of both techniques, it is necessary to consider some aspects related to how each method represents the watershed erosion processes. The sediment traps produce values of percentage of organic matter sedimentation, since part of this material could have been degraded in the consolidated lake sediment. On the other hand, the traps underestimate the quantity of total sediment, since they do not collect the sediment that reaches the bottom through lateral "focusing" movement bellow the height of the trap's entrance (Håkanson, 1977; Crusius and Anderson, 1995). Assuming certain compensation between both factors, the value obtained in 1997 with sediment traps $\left(1.9 \mathrm{~kg} \mathrm{~m}^{-2}\right)$ would be comparable to the average of the years when the tourism related erosion was more intense. Therefore, the values obtained between 1999 and 2003 (between 0.22 and $0.56 \mathrm{~kg} \mathrm{~m}^{-2}$ ) would be comparable to the mean values of the years preceding the impact of tourism.

\section{Climate change detection through the study of sediment subfossil chironomid}

A paleolimnological study was carried out in Cimera Lake sediment, where some changes were observed in the diversity and abundance of the chironomid head capsules in the more recent sediment layers. It wasn't possible to detect the possible sources of direct impacts on the lake that could be responsible for the biological changes during this period (Granados \& Toro, 2000a). To explain these changes a hypothesis about a possible influence of local climate change (temperature) on chironomids communities was tested by temperature reconstruction.

Several authors have used the subfossil chironomid to develop temperature reconstruction models (Walker et al., 1991; Lotter et al., 1997: Olander et al., 1997), though none of them is specific for the Iberian Peninsula. Granados and Toro (2000a) used the model developed by Lotter et al. (1997) in the Alps to estimate the summer mean temperature (June, July and August), since it is the mountainous region biogeographically most similar to the Iberian Peninsula, with a similar species composition. The Cimera Lake species taxonomy was previously harmonized with the one use in the model, to avoid incoherence in its application. Figure 18 shows the mean summer temperature reconstruction by way of subfossil chironomid transfer functions, as well as by the use of long term climate series (Agusti-Panareda \& Thompson, 2002). When applying the transfer functions developed to reconstruct summer past temperatures in the Alps to fossil chironomids of the Cimera Lake, it is also well correlated with reconstructed air temperatures $(n=20$, $r=0.45, p<0.01$ ), especially when only the most accurate dating levels (top of the core, ca 75 years $)$ are taken into account $(n=13$, $\mathrm{r}=0.75, \mathrm{p}<0.01)$. However, 1) the linear regressions of both models show significantly different slopes, and 2) chironomid reconstruc- 

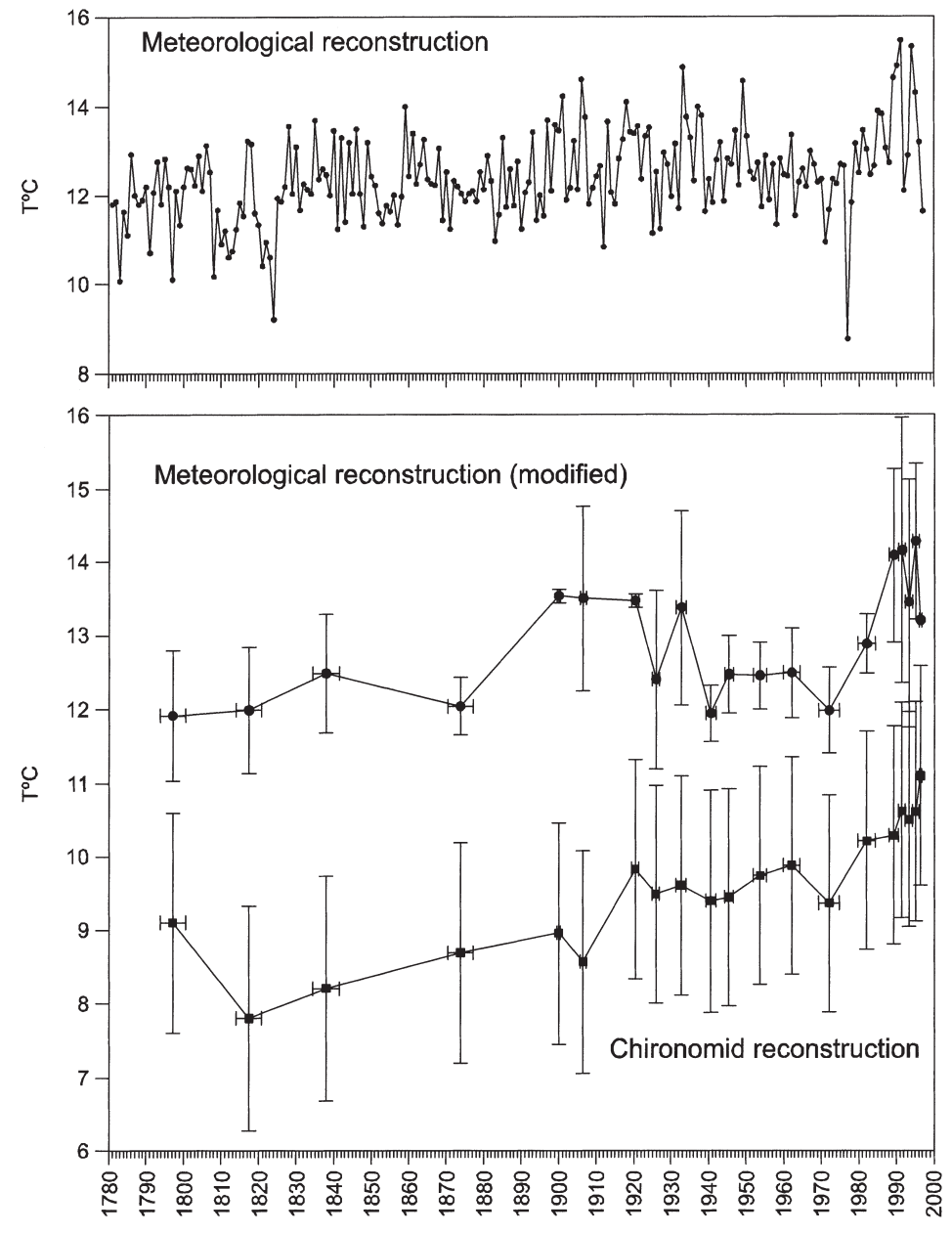

Year

Figure 18. Upper graph: Reconstructed annual mean summer air temperatures using long climate series (Agusti-Panareda \& Thompson, 2002). Lower graph: Reconstructed mean summer air temperatures in Lake Cimera by means of climate model and chironomids calibration model (Granados \& Toro, 2000). Gráfica superior: Reconstrucción de las temperaturas del aire medias anuales del verano mediante largas series climáticas (Agusti-Panareda \& Thompson, 2002). Gráfica inferior: Reconstrucción de las temperaturas del aire medias del verano en la laguna Cimera mediante un modelo climático y un modelo de calibración basado en el análisis de quironómidos (Granados \& Toro, 2000).

tion underestimates air reconstruction in ca. $3{ }^{\circ} \mathrm{C}$. The later is probably because the fossil chironomid model has been developed for a different geographical region. Nevertheless, the results of the two different and independent models suggest the existence of an environmental warming of over $1.5^{\circ} \mathrm{C}$ in the summer mean temperature since the $1980 \mathrm{~s}$ in the Central Range mountains. Our data also supports the use of chironomid head capsules as an effective tool for past temperatures inference.

\section{The introduction of the brook trout}

The effects of the introduction of the brook trout (Salvelinus fontinalis), a salmonid from the northeast region of North America, have been studied in one of the Central Range lakes (Peñalara Lake). Although this species was introduced in Spain at the end of the $19^{\text {th }}$ century (Gómez Caruana \& Díaz Luna, 1991), it was in the 1970s that mountain rivers and lakes were populated for sport fishing purposes. The brook 
trout eats mainly aquatic invertebrates, though it preys upon a large range of organisms throughout its life cycle (zooplankton, juvenile fish, amphibious larvae) (Massabuau, 1997; Mullen, 1958; Newman \& Dubois, 1996; Scott \& Crossman, 1973), causing, besides, nutrient cycling in the lake water (mainly phosphorus), stimulating primary production (Slusarczyk, 1997) and causing an important alteration in the lake ecosystem. Before the introduction of the brook trout, there were no fish species in the Peñalara Lake, as reported by researchers or naturalists who visited the lake in that period (Margalef, 1949; Arévalo, 1921, 1931). Besides, the existence of a small cascade in the lake outlet would be a barrier for the fish to swim upstream to colonize the lake.

During 1997 a field experiment in situ was carried out in the lake to test the effects of fish predation on aquatic invertebrates by using two types of limnological enclosures, pelagic and littoral, to prevent the access of fishes. The results obtained with the shore limnological enclosures do not reflect differences in the species composition within and outside these enclosures. A year is probably not a long enough period to observe the re-colonization of aquatic organisms. Nevertheless, in some larger macroinvertebrate taxa, some differences were observed in the densities of the communities inside and outside the limnological enclosures, probably as a response to the presence/absence of the brook trout (Fig. 19). About the macroinvertebrates communities (littoral enclosures), the tricoptera and megaloptera, the larger sized taxa in the lake, have a larger population density inside the enclosures (Fig. 19a). There are no significant differences in the coleoptera present, small in size. Those taxa which live on top of the substrate (e.g. tricoptera) are more susceptible to the brook trout predation than the species which live buried in the sediment. In the presence of brook trout, no swimming or pelagic taxa individuals have been detected. The diptera of the chironomid and ceratopogonid families, of small size, were not different in both environments. However, the tabanids, larger sized, had a slightly higher density inside the limnological enclosures. The oligochaetes have a higher population density outside the enclosures, while the only bivalve species found in the lake tends to have a higher density inside the enclosures. The Peñalara Lake diversity has been much lower during the years with brook trout presence (9-13 species during the introduction, compared to 23 after its eradica-

Table 3. Zoooplanktonic crustacea recorded in Peñalara Lake. In 1995 and 1997 columns, the percentage of samples with each taxa is indicated. Maximum length is related to partenogenetic female about cladocera (according to Alonso, 1996), but in copepoda it is related to both sexes (according to Dussart, 1969). Crustáceos zooplanctónicos citados en la laguna de Peñalara. Para los años 1995 y 1997 se cita entre paréntesis el porcentaje de muestras en que se ha encontrado cada especie. La longitud máxima se refiere a la de la hembra partenogenética en los cladóceros, según Alonso (1996), mientras que en los copépodos se presenta la longitud máxima para ambos sexos, según Dussart (1969).

\begin{tabular}{|c|c|c|c|c|}
\hline & $\begin{array}{l}\text { Margalef, } 1949 \\
\text { (1 sampling) }\end{array}$ & $\begin{array}{l}\text { Toro \& Montes, } 1995 \\
\quad \text { (13 samplings) }\end{array}$ & $\begin{array}{l}\text { Toro \& Granados, } 1997 \\
\quad \text { (17 samplings) }\end{array}$ & Maximum lenght \\
\hline \multirow[t]{6}{*}{ Cladocera } & $\begin{array}{l}\text { Daphnia pulex } \\
\text { (= pulicaria) }\end{array}$ & --- & --- & $2.5 \mathrm{~mm}$ \\
\hline & $1-1$ & --- & Daphnia longispina (18 \%) & $2.3 \mathrm{~mm}$ \\
\hline & --- & 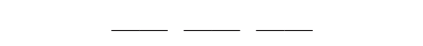 & Ceriodaphnia reticulata & $1.3 \mathrm{~mm}$ \\
\hline & --- & Ceriodaphnia & Ceriodaphnia quadrangula (82\%) & $0.8 \mathrm{~mm}$ \\
\hline & $-\longleftarrow$ & Alona quadrangularis (23\%) & Alona quadrangularis (47\%) & $0.8 \mathrm{~mm}$ \\
\hline & --- & Chydorus sphaericus (92\%) & Chydorus sphaericus (76\%) & $0.5 \mathrm{~mm}$ \\
\hline \multirow[t]{3}{*}{ Copepoda } & $\begin{array}{c}\text { Eucyclopslilljerborgi } \\
\text { (=serrulatus) }\end{array}$ & Eucyclops serrulatus (46\%) & Eucyclops serrulatus (12\%) & \multirow{3}{*}{ 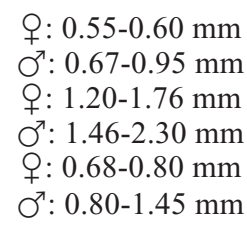 } \\
\hline & & Tropocyclops prasinus (100\%) & Tropocyclops prasinus $(94 \%)$ & \\
\hline & 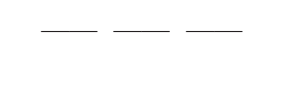 & 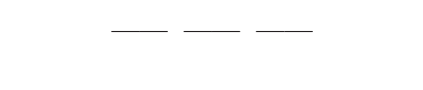 & Cyclops strenuus (6 \%) & \\
\hline
\end{tabular}



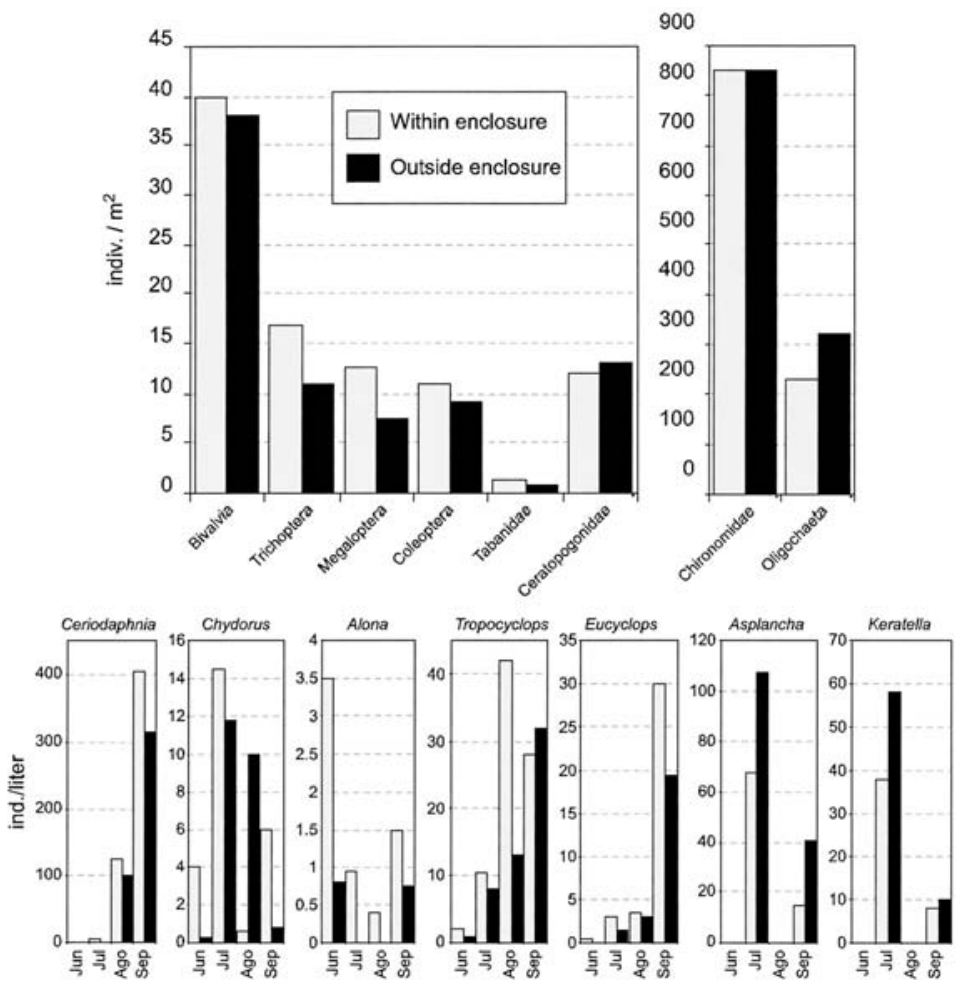

Figure 19. Differences observed in the densities of the aquatic invertebrates communities inside (fish absence) and outside (fish presence) the limnological enclosures in Peñalara lake during Summer 1997. a) Macroinvertebrates in littoral enclosures. b) Zooplankton in pelagic enclosure. Diferencias observadas en las densidades de las comunidades de invertebrados acuáticos dentro (con ausencia de peces) y fuera (con presencia de peces) de los limnocorrales instalados en la laguna de Peñalara durante el verano de 1997. a) Macroinvertebrados en los limnocorrales litorales. b) Zooplankton en el limnocorral pelágico.

tion) when compared to the macroinvertebrate communities found in other Peñalara Natural Park ponds or lakes (Toro y Granados, 1998), where there are no fish species. In the case of the pelagic limnological enclosure, the densities of organisms (zooplankton) both inside and outside were relatively small, though presenting significant differences, and there were no differences in species composition in the two environments (Fig. 19b). The cladocera Ceriodaphnia reticula$t a$, not cited before in this lake, much larger (maximum length: $1.3 \mathrm{~mm}$ ) than the Ceriodaphnia species previously cited, quickly appeared in the enclosure, reaching higher densities in the absence of the brook trout pressure. The second cladocera species of larger size, Alona quadrangularis, had a lower density outside the enclosure. The third cladocera species found, Chydorus sphaericus, smaller in size and with a low and irregular density in both environments, had slight larger numbers inside the enclosure. Regarding the copepods, the two species found had a similar size (Tropocyclops prasinus and Eucyclops serrulatus), and had similar population densities, though with a trend for higher densities within the enclosure. Lastly, the two rotifer species identified (Asplancha priodonta and Keratella quadrata) presented the opposite trend, with a higher population density outside the enclosure, in the presence of the brook trout.

Comparing the results of this and recent studies (Toro and Montes, 1993; Toro and Granados, 1997) after the fish introduction to the species composition data in Margalef's historic research, previous to the introduction of the brook trout (Table 3), there are some interesting changes, which are probably related to the introduction of this salmonid. Margalef (1949) only cites 2 species of plankton crustaceous in the Peñalara Lake: Daphnia pulex and Eucyclops lilljerborgi, 
which possibly would be correspond with $D$. pulicaria and E. serrulatus according to upto-date or later taxonomy (Alonso, 1996; Dussart, 1969, Margalef, 1953). In order to give a comparison of relative sizes of each species, there is a column with the species maximum length, since this is an essential factor in the probability of being predated by a brook trout. The difference in the number of species found is probably due to the fact that Margalef cited species found in one single sampling day (April $29^{\text {th }}$, 1949), while the other authors integrated the species found in 30 lake samplings, varying between 2 and 4 species per sample. After the brook trout introduction, two crustaceans clearly dominated: Ceriodaphnia quadrangula and Tropocyclops prasinus, representing at least $50 \%$ of the individuals present, being frequently found with Chydorus sphaericus and, in a smaller proportion, with Alona quadrangularis and Eucyclops serrulatus, all species of small or medium size. On the other hand, the larger species, the cladocera Daphnia longispina and the copepod Cyclops strenuus, are only found sporadically and always represent less than $5 \%$ of the total of individuals in a sample. Margalef's citation in 1949 of the presence of Daphnia pulex (= D. pulicaria), a macrofilterfeeder of a large relative size, without other smaller sized cladocera, is possibly evidence that the presence of this predator has clearly favored the smaller species in relation to the macrofilters. Besides, Margalef (1949) himself comments that "the absence of planktonic rotifers is remarkable", while ten species of this group have been found in later samplings. The changes in the rotifer community structure caused by different fish population densities have been observed in experiments in other lakes (Stenson, 1982). In summary, the larger species tend to dominate in the zooplankton not submitted to the brook trout pressure. The copepod and cladocera population densities are higher inside the limnological enclosure. In contrast, the density of rotifers is higher outside the limnological enclosure. The brook trout juvenile stages have predominantly plantivore habits, although their incidence is directly proportional to the zoo- plankton species size. The rotifers, microscopic organisms, would be, thus, benefited by the brook trout presence, being able to use the trophic resources that would be otherwise consumed by the larger species in the zooplankton. As additional information, Bosch et al. (2000) observe that the common salamander (Salamandra salmandra) and the midwife toad (Alytes obstetricans) reproduced in the lake before the introduction of the brook trout. There are no citations of salamander larvae after the introduction of the brook trout (Bosch et al., 2002).

The results of the experiments with shore and pelagic limnological enclosures, as well as the existing historic data, reflect remarkable changes in the aquatic vertebrate community structure in the lake, due to the brook trout predatory activity. The negative effect that the fish fauna can have on the benthonic and planktonic communities has been demonstrated in other lakes: Braña et al. (1996) found a significant decrease in the abundance of amphibious larvae in high mountain lakes in the Cantabric Range in relation to those without fish; Balvay (1978) observed the almost complete disappearance of benthos just a few years after the introduction of salmonids in a lake in the French Alps. Johnson et al. (1996) demonstrated a clear decrease in the number of benthonic (triclads, mollusks, odonate, ostracode) and planktonic (large sized daphnid) invertebrates due to predation by fish in mesocosmos experiments. Therefore, the eradication of the brook trout in the lake was proposed, in order to recover the aquatic population previous conditions. In order to achieve this, gill nets were used for 5 years, until the total absence of the brook trout was confirmed. Before the brook trout eradication, the maximum number of aquatic invertebrate families in the months without the ice cover (1991-2000) was 9-13. This taxonomic richness increased to 14 families in 2001, with a reduced brook trout population. Once the brook trout was eradicated, 17 families were found during the period without the ice cover in 2002, and 23 families were found in the two following years (2003 and 2004). It is evident that the brook trout eradication has brought about an increment in the taxo- 
nomic richness of the macroinvertebrate fauna, and an absolute transformation in the benthonic macroinvertebrate community. Practically all the species that inhabited the lake before the eradication maintained their population, and a large number of taxa, mainly large sized aquatic insects, were added to the community. These taxa have been found in other Natural Park ponds and lakes (Toro y Granados, 1998), from which they were able to re-colonize the lake once their predator was eliminated.

\section{CONCLUSIONS}

The ecological characteristics of the Iberian Peninsula Central Range high mountain lakes make them extraordinary sensors for natural or human induced environmental change. The chemical composition of their waters, their thermal and hydrological dynamics, as well as their biological communities respond with high sensitivity to changes in climate variables such as temperature or precipitation, to excess nutrients from the watershed or the atmosphere, to erosion processes related to tourism or cattle raising activities, to water regulation by damming, to the introduction of exotic species, or to the organic contamination of the water. However, their self-recovery capacity once the pressure or the origin of the impact is eliminated is also extraordinary, due, mainly, to their high water turnover rates.

One of the main contributions of this work is the joint utilization of paleoinformation and modern monitoring systems as support for management and restoration of the lake ecosystems and their watersheds. Besides, the importance of the historic information provided by the first researchers who dedicated their efforts to discover remote, unaltered ecosystems, leaving a writte heritage of invaluable documental and scientific importance, is emphasized.

Finally, this work contributes indirectly by stressing the importance of communication and of cooperation between scientists and managers, in order to achieve a greater efficiency in environmental conservation and to technically back up management measures. The need for institutional support to develop long-term monitoring systems which can provide invaluable information about local, regional and global trends is also emphasized.

\section{ACKNOWLEDGEMENTS}

This research has been funded by following institutions and projects: The Natural Park of Peñalara (Consejeria de Medio Ambiente, Regional Government of Madrid), the Delegación Territorial de Ávila (Consejería de Medio Ambiente y Ordenación del Territorio, Junta de Castilla y León), Acciones Integrades between UK (British Council) and Spain (M.E.C.) No. 93A (1991-1992), MOLAR project (EU contract ENV4-CT95-0007). Collaborators from the Department of Ecology (Universidad Autónoma de Madrid), Natural Park of Peñalara staff and personnel from the Mountain Refuge Elola (Sierra de Gredos) have helped in field or laboratory works since the beginning of the projects.

\section{REFERENCES}

ABBOTT, M. B., B. B. WOLFE, A. P. WOLFE, G. O. SELTZER, R. ARAVENA, B. G. MARK, P. POLISSAR, D. T. RODBELL, H. D. ROWE \& M. VUILLE. 2003. Holocene paleohydrology of the central Andes using multiproxy lake sediments. Palaeogeogr. Palaeoclimatol. Palaeoecol., 194: 123-138.

AGUSTI-PANAREDA, A. \& R. THOMSON. 2002. Reconstructing air temperature at eleven remote alpine and artic lakes in Europe from 1781-1997 AD. J. Paleolimnol., 28 (1): 7-23.

ALDASORO, J. J., C. DE HOYOS, B. DE VICUNA y J. C. VEGA. 1984. Comunidades de plantas macrofitas y de crustaceos en las lagunas de montana del NW de Espana. Limnetica, 1: 111-115.

ALDASORO, J. J. y M. TORO. 2001. La vegetación acuática. En: Las lagunas del Parque Regional de la Sierra de Gredos. M. Toro \& I. Granados (eds.): 67-77. Monografías de la Red de Espacios Naturales de Castilla y León. Serie Técnica: Junta de Castilla y León. Valladolid.

ALONSO, M. 1996. Crustacea, Branchiopoda. En: Fauna Ibérica, Vol. 7. M.A. Ramos et al. (eds.): 1486. Museo Nacional de Ciencias Naturales. CSIC. Madrid. 
APPLEBY, P. G., P. NOLAN, D. W. GIFFORD, M. J. GODFREY, F. OLDFIELD, N. J. ANDERSON \& R. W. BATTARBEE. $1986 .{ }^{210} \mathrm{~Pb}$ dating by low background gamma counting, Hydrobiologia, 141: 21-27.

APHA. 1992. Métodos Normalizados Para el Análisis de Aguas Potables y Residuales. Madrid. Ediciones Díaz de Santos S.A. 1576 pp.

AREVALO, C. 1921. Larvas planktónicas de arquípteros de la Laguna de Peñalara. Mem.Real Soc.Esp.Hist.Nat., Tomo 50 aniv.: 169-172.

AREVALO, C. 1931. Los monstruos de la laguna de Peñalara. Cultura Segoviana, 1: 19-22.

ARPE, K. \& E. ROECKNER. 1999. Simulation of the hydrological cycle over Europe: Model validation and impacts of increasing greenhouse gases. Advances in Water Resources, 23 (2): 105-119.

AZNAR, G. 1839. Viage a la Sierra y laguna de Gredos por su polo austral. Madrid. $16 \mathrm{pp}$.

AZPEITIA, F. 1911. La diatomología española en los comienzos del siglo XX. Asoc. Esp. Progr. Cienc. Secc. $3^{a}$ Cienc. Nat. 320 pp.

BALTANAS, A. 1985. Variación temporal de la fauna de invertebrados de una charca temporal, con especial referencia a la taxocenosis de crustáceos. Tesina de licenciatura. Universidad Autónoma de Madrid. 194 pp.

BALVAY, G, 1978. Un lac oligotrophe de haute montagne: le lac cornu (Haute-Savoi). Revué de geógraphie alpine, 66: 31-41.

BARICA, J. 1977. Effect of freeze-up on major ion and nutrient content of a prairie winterkill lake. $J$. Fish. Res. Bd. Can., 34: 2210-2215.

BARON, J. (Ed.). 1992. Biogeochemistry of a subalpine ecosystem. Loch Vale watershed. Ecol. Stud., vol. 90. Springer-Verlag, New York. 247 pp.

BATTARBEE, R. W. 1986. Diatom analysis. In: Handbook of Holocene Palaeoecology and Palaeohydrology. B.E. Berglund (ed.): 527-570. J. Wiley \& Sons, Chichester.

BATTARBEE, R. W. \& I. RENBERG. 1990. The Surface Water Acidification Project (SWAP) Palaeolimnology Programme. Philosophical Transactions of the Royal Society, London B, 327: 227-232.

BATTARBEE, R. W., J. A. GRYTNES, R. THOMPSON, P. G. APPLEBY, J. CATALAN, A. KORHOLA, H. J. B. BIRKS, E. HEEGAARD, \& A. LAMI. 2002. Comparing paleolimnological and instrumental evidence of climate change for remote mountain lakes over the last 200 years. Journal of Paleolimnology, 28(1): 161-179.

BOAVIDA, M. J. 2000. Os lagos da Serra de Estrela (Portugal). En: Conservación de Lagos y
Humedales de Alta Montaña de la Península Ibérica. I. Granados y M. Toro (eds.): 79-86. Servicio de Publicaciones de la Universidad Autónoma de Madrid.

BOSH, J., I. MARTÍNEZ-SOLANO y M. GARCÍAPARÍS. 2000. Anfibios de Peñalara. Consejería de Medio Ambiente, Comunidad de Madrid. Vols. 1 y 2.

BOSCH, J., P. A. RINCÓN, I. MARTÍNEZ-SOLANO y L. BOYERO. 2002. Estado de Conocimiento de la Fauna de Peñalara. Anfibios. Consejería de Medio Ambiente, Comunidad de Madrid. 80 pp.

BRAÑA, F., L. FRECHILLA \& G. ORIZAOLA. 1996. Effect of introduced fish on amphibian assemblages in mountain lakes of northern Spain. Herpetological Journal, 6: 145148.

BRINKHURST, R. O. 1971. A Guide for the identification of british Aquatic Oligochaeta. Freshwater Biological Association Scientific Publication, N. 22.

CABALLERO, F. 1944. Algas del macizo de Gredos. Anales Jard. Bot. Madrid, 5(2): 345-364.

CABALLERO, F. 1950. Algas del macizo de Gredos (Segunda parte). Anales Jard. Bot. Madrid, 10(1): 231-260.

CAMARERO, L., J. CATALAN, A. BOGGERO, A. MARCHETTO, R. MOSELLO \& R. PSENNER, 1995a. Acidification in high Mountain Lakes in Central, Southwest, and Southeast Europe (Alps, Pyrennees, Prin). Limnologica, 25(2): 141-156.

CAMARERO, L., J. CATALAN, S. PLA, M. RIERADEVALL, M. JIMÉNEZ, N. PRAT, A. RODRÍGUEZ, L. ENCINA, L. CRUZ-PIZARRO, P. M. SÁNCHEZ CASTILLO, P. CARRILLO, M. TORO, J. O. GRIMALT, L. BERDIE, P. FERNÁNDEZ \& R. VILANOVA. 1995b. Remote mountain lakes as indicators of diffuse acidic and organic pollution in the Iberian Peninsula (AL:PE 2 Estudies). Water, Air and Soil Pollution, 85: 487-492.

CARRERA, G., P. FERNANDEZ, J. O. GRIMALT, M. VENTURA, L. CAMARERO, J. CATALAN, U. NICKUS, H. THIES \& R. PSENNER. 2002. Atmospherc deposition of organochlorine compounds to remote high mountain lakes of Europe. Environ. Sci. Technol., 36(12): 2581-8.

CASADO, S. 2000. Ilusiones alpinas. Los orígenes de la investigación científica sobre lagos y humedales de alta montaña en España. En: Conservación de Lagos y Humedales de Alta Montaña de la Península Ibérica. I. Granados y M. Toro (eds.): 19-32. Colección de Estudios $\mathrm{N}^{\circ}$ 63. Servicio de Publicaciones de la Universidad Autónoma de Madrid. 
CASTRO, M., C. FERNANDEZ, M. A. GAERTNER, \& C. GALLARDO. 1995. Relevance of regional models for analyzing future climate change in the Iberian Peninsula. In: Global change and Mediterranean-type ecosystems. J. M. Moreno \& W.C. Oechel (eds.): 1-34. Ecological Studies, 117. Springer.

CATALAN LAFUENTE, J. G. 1990. Química del agua. Ed. Bellisco. Madrid. 423 pp.

CATALAN, J. y LL. CAMARERO. 1988. Determinación de los componentes del sistema carbónico-carbonatos de las aguas dulces mediante la titulación de Gran. Tecnología del agua, 51: 66-75.

CATALAN, J., S. PLA, M. RIERADEVALL, M. FELIP, M. VENTURA, T. BUCHACA, L. CAMARERO, A. BRANCELJ, P. G. APPLEBY \& A. LAMI. 2002. Lake Redó ecosystem response to an increasing warming in the Pyrenees during the twentieth century. J. Paleolimnol.,28(1): 129-145.

CRUSIUS, J. \& R. F. ANDERSON. 1995. Sediment focusing in six small lakes inferred from radionuclide profiles. J. Paleolimnol., 13: 143-155.

CRUZ-PIZARRO, L., R. MORALES-BAQUERO \& A. GONZÁLEZ. 1981. Descripción del ciclo anual de desarrollo del zooplancton de un lago de alta montaña mediante un análisis factorial. Act. I Congr. Esp. Limnol., 69-74.

CURTIS, C. J., M. POSCH, P. CASALS-CARRASCO, J. CATALAN, M. HUGHES, M. KERNAN \& M. VENTURA. 2005. The significance of European high mountain lakes in critical load distributions at the EMEP grid scale. Aquat. Sci., 67: 252-262.

DEARING, J. 1986. Core correlation and total sediment influx. En: Handbook of Holocene Palaeoecology and Palaeohydrology. B.E. Berglund (ed.): 247-272. J.Wiley \& Sons, Chichester.

DE HOYOS, C. y A. NEGRO. 2001. Fitoplancton. En: Las lagunas del Parque Regional de la Sierra de Gredos. M. Toro \& I. Granados (eds.): 79-103. Monografías de la Red de Espacios Naturales de Castilla y León. Serie Técnica: Junta de Castilla y León. Valladolid.

DE PEDRAZA, J. y J. LÓPEZ. 1980. Gredos. Geología y glaciarismo. Trazo-Editorial. Zaragoza. $31 \mathrm{pp}$.

DUSSART, B. 1969. Les copépodes des eaux continentales d'Europe occidentale. Tome 2: Cyclopoïdes et Biologie. Ed. Boubée \& Cie, Paris. 292 pp.

ELLIOT, J. M. \& K. H. MANN. 1979. A key to British Freshwater Leeches with notes on their life cycles and ecology. Freshwater biological Association Scientific Publication, N. 49.
FERNÁNDEZ, P., N. L. ROSE, R. L. VILANOVA \& J. O. GRIMALT. 2002. Spatial and temporal comparison of polycyclic aromatic hydrocarbons and spheroidal carbonaceous particles in remote European lakes. Water, Air and Soil Pollution Focus, 2: 261-274.

GLEW, J. R. 1988. A portable extruding device for close interval sectioning of unconsolidated core samples. J. Palaeolimnology, 1: 235-239.

GLEW, J. R., J. P. SMOL \& W. M. LAST. 2001. Sediment core collection and extrusion. In: Tracking Environmental Change Using Lake Sediments. Vol 1: Basin Analysis, Coring, and Chronological Techniques. W. M. Last \& J. P. Smol (eds.): 73-105. Kluwer Academic Publishers, Dordrecht.

GOMEZ CARUANA, F. \& J. L. DÍAZ LUNA. 1991. Guía de los peces continentales de la Península Ibérica. Madrid. Ed. Acción Divulgativa. 339 pp.

GONZÁLEZ GUERRERO, P. 1927. Contribución al estudio de las algas y esquizófitas de España. Trab. Mus. Nac. Cienc. Nat. (Ser. Bot.), 22: 1-52.

GONZÁLEZ GUERRERO, P. 1929a. Nuevos datos del plankton hispano-marroquí (agua dulce). Bol. Real Soc. esp. Hist. Nat., 29: 251-254.

GONZÁLEZ GUERRERO, P. 1929b. De la ficoflora hispano-marroquí (agua dulce). Bol. Real Soc. esp. Hist. Nat., 29: 361-364.

GONZÁLEZ GUERRERO, P. 1965. Algas de la sílice (Guadarrama). Annls. Inst. Bot. Cavanilles, 23: 107-144.

GRANADOS, I. y M. TORO. 2000a. Recent Warming in a High Mountain Lake (Laguna Cimera, Central Spain) Inferred by Means of Fossil Chironomids. Journal of Limnology, 59 (Suppl. 1): 109-119.

GRANADOS, I. y M. TORO. 2000b. Limnología en el Parque Natural de Peñalara: Nuevas aportaciones y perspectivas de futuro. Actas de los Segundos Encuentros Cientificos del Parque Natural de Peñalara y Valle del Paular. Consejería de Medio Ambiente, Comunidad de Madrid: 55-72.

GRANADOS, I., M. TORO, S. ROBLES, J. M. RODRÍGUEZ, M. C. GUERRERO y C. MONTES. 2002. La paleolimnología como fuente de información ambiental: ejemplos de las lagunas de alta montaña del Sistema Central. Actas de los Terceros Encuentros Científicos del Parque Natural de Peñalara y Valle de El Paular. Consejería de Medio Ambiente, Comunidad de Madrid: 17-32.

HÅKANSON, L. 1977. The influence of wind, fetch and water depth on the distribution of sediments 
in Lake Vanern, Sweden. Can. J. Earth Sci., 14: 397-412.

HÄKANSON, L. 1981. A manual of lake morphometry. Springer-Verlag. Berlin.

HAUER, F. R., J. S. BARON, D. H. CAMPBELL, K. D. FAUSCH, S. W. HOSTETTLER, G. H. LEAVESLEY, P. R. LEAVITT, D. M. MACKNIGHT \& J. A. STANFORD. 1997. Assessment of climate change and freshwater ecosystems of the Rocky Mountains, USA and Canada. Hydrologic Processes, 11: 903-924.

HAUSMANN, S., A. F. LOTTER, J. F. N. LEEUWEN, C. OHLENDORF \& M. STURM. 2001. The influence of land-use and climate change on Alpine lakes: a high-resolution case study focusing on the past 1000 years. Terra Nostra, 3: 96-99.

JEFFREY, S. W. \& G. F. HUMPHREY. 1975. New spectrophotometric equations for determining chlorophylls a, b, c1 and c2 in higer plants, algae and natural phytoplankton. Biochem. Physiol. Pflanzen., 167: 191-194.

JOHNSON,D. M., T. H. MARTIN, P. H. CROWLEY \& L. B. CROWDER. 1996. Link strength in lake littoral food webs: Net effects of small sunfish and larval dragonflies. J. N. Amer. Benthol. Soc., 15: 271288.

KOPACEK, J., E. STUCHLIK, V. VYHNALEK \& D. ZAVODSKY. 1996. Concentration of nutrients in selected lakes in the high Tatra mountains, Slovakia: Effect of season and watershed. Hydrobiologia, 319: 47-55.

KROL, J., M. BENVENUTI y J. ROMANO. 1997. Ion Analysis Methods for IC and CIA and Practical Aspects of Capillary Ion Analysis Theory. Waters Corporation.

LAGNTON, P. H. 1991. A key to pupal exuviae of West Paleartic Chironomidae. Author's Personal Publication. 386 pp.

LAMI, A., P. GUILIZZONI, A. MARCHETTO, R. BETTINETTI \& D. J. SMITH. 1998. Palaeolimnological evidence of environmental changes in some high altitude Himalayan lakes (Nepal). Mem. Ist. ital. Idrobiol., 57: 107-130.

LIVINGSTONE, D. M. 2005. Anthropogenic influences on the environmental status of remote mountain lakes. Aquat. Sci., 67: 221-223.

LIZANA, M. \& J. MORALES. 2001. Vertebrados acuáticos y semiacuáticos. En: Las lagunas del Parque Regional de la Sierra de Gredos. M. Toro \& I. Granados (eds.): Monografías de la Red de Espacios Naturales de Castilla y León. Serie Técnica: Junta de Castilla y León. Valladolid.
LOTTER, A. F., H.J.B.BIRKS, W. HOFMANN \& A. MARCHETTO. 1997. Modern diatom, cladocera, chironomid and chrysophyte cyst assemblages as quantitative indicators for the reconstruction of past environmental conditions in the Alps. 1. Climate. J. Paleolimnol., 18: 395-420.

LUCEÑO, M. \& P. VARGAS. 1991. Guía botánica del Sistema Central español. Madrid. Ed. Piramide. 354 pp.

LUQUE, J. A. \& R. JULIA. 2002. Lake sediment response to land-use and climate change during the last 1000 years in the oligotrophic Lake Sanabria (northwest of Iberian Peninsula). Sedimentary Geology, 148 (1-2): 343-355.

MARCHETTO, A. \& M. ROGORA. 2004. Measured and modelled trends in European mountain lakes: results of fifteen years of cooperative studies. $J$. Limnol., 63(1): 55-62.

MARCHETTO, A., R. MOSELLO, R. PSENNER, G. BENDETTA, A. BOGGERO, D. TAIT \& G. A. TARTARI. 1995. Factors affecting water chemistry of alpine lakes. Aquat. Sci., 57: 81-89.

MARGALEF, R. 1949. Datos para la hidrobiología de la Sierra de Guadarrama. P. Inst. Biol. Apl., Tomo VI: 5-21.

MARGALEF, R. 1953. Los crustáceos de las aguas continentales ibéricas. Instituto Forestal de Investigaciones y Experiencias. Ministerio de Agricultura. Madrid. 300 pp.

MARTÍNEZ, F. 1999. Los bosques de P. Sylvestris del Sistema Central español. Distribución, Historia, Composición Florística y tipología. Tesis Doctoral, Universidad Complutense de Madrid. $701 \mathrm{pp}$.

MARTÍNEZ-MOLINA, I., M. T. MARTÍNEZ-MARTÍNEZ, \& S. ALARCON. 1984. Climatología de Puerto de Navacerrada. Pub. Inst. Nac. Meteor. A91, $79 \mathrm{pp}$.

MARTÍNEZ-SOLANO, I., M. GARCÍA-PARIS \& J. BOSCH. 2002. Los anfibios de Peñalara: evaluación de su estado de conservación y bases para su gestión. Terceras Jornadas Cientificas del Parque Natural de Peñalara y del Valle del Paular. Consejería de Medio Ambiente, Comunidad de Madrid: 53-64.

MASSABUAU, J. C. 1997. Looking for artic charr in remote mountain lakes. Centre National de la Recherche Scientifique. Formato Video VHS. 13 $\min$.

MIRACLE, M. R. 1978. Composicion especifica de las comunidades zooplanctonicas de 153 lagos de los pirineos y su interes biogeografico. Oecologia aquatica, 3: 167-191. 
MOLAR Water Chemistry Group. 1999. The MOLAR Project: atmospheric deposition and lake water chemistry. J. Limnol., 58(2): 88-106.

MONSERRAT, J. M. 1992. Evolución glaciar y postglaciar del clima y la vegetación en la vertiente Sur del Pirineo: Estudio palinológico. Monografías del Instituto Pirenaico de Ecología, 6.

MORALES-BAQUERO, R., P. CARRILLO, I. RECHE \& P. SÁNCHEZ-CASTILLO. 1999. Nitrogen-phosphorus relationship in high mountain lakes: effects of the size of catchment basins. Can. J. Fish. Aquat. Sci., 56: 1809-1817.

MORALES-BAQUERO, R., C. PÉREZ-MARTÍNEZ \& I. RECHE. 2001. Ecosistemas de alta montaña, las atalayas de la troposfera. Ecosistemas, 3: 1-5

MULLEN, J. W. 1958. A compendium of the life history and ecology of the eastern brook trout, Salvelinus fontinalis Mitchell. The Massachusetts Division of Fisheries and Game. Fish Bull., 23: 37 pp.

NEWMAN L. E. y R. B. DUBOIS (eds.). 1996. Status of brook trout in Lake Superior. Prepared for the Lake Superior Technical Committee by the Brook Trout Subcommittee. Great Lakes Fish. Comm. http://www.glfc.org/pubs_out/docs.htm

N.R.C. (National Research Council, Committee on the Geological Record of Biosphere Dynamics) (K.W. Flessa (Chair), S. T. Jackson (Vice-Chair). J. D. Aber, M. A. Arthur, P. R. Crane, D. H. Erwin, R. W. Graham, J. C. B. Jackson, S. M. Kidwell, C. G. Maples, C. H. Peterson, O. J. Reichman). 2005. The Geologic Record of Ecological Dynamics: Understanding the Biotic Effects of Future Environmental Change. National Academy Press, Washington, D.C. 200 pp.

OBERMAIER, H. y J. CARANDELL. 1917. Los glaciares cuaternarios de la Sierra de Guadarrama. Trab. Museo Nac. Cienc. Nat. (Ser. Geol.), 19: 1-75.

OLANDER, H., A. KORHOLA \& T. BLOM. 1997. Surface sediment Chironomidae (Insecta: Diptera). Distribution along an ecotonal transect in subartic Fennoscandia: Developing a tool for palaeotemperature reconstructions. J. Paleolimnol., 18: 45-59.

PARDO, L. 1932. La Laguna de Peñalara (Segovia). En: Lagos de España. 51-56. Valencia. Impr. Hijo de F. Vives Mora.

PARDO, L. 1948. Catálogo de los lagos de España. Inst. Forestal Inv. Exp. 522 pp.

PARR, T. W., SIER, A. R. J., BATTARBEE, R. W., MACKAY, A. W. \& BURGESS, J. 2003. Detecting environmental change: science and society - perspectives on long-term research and monitoring in the 21 st century. The Science of the Total Environment, 310 (1-3): 1-8.

PASCUAL, M., A. RODRÍGUEZ-ALARCÓN, J. HIDALGO, F. BORJA, F. DÍAZ \& C. MONTES. 2000. Distribución y caracterización morfológica y morfométrica de los lagos y lagunas de alta montaña de la España peninsular. En: Conservación de Lagos y Humedales de Alta Montaña de la Península Ibérica. I. Granados y M. Toro (eds.): 51-77. Colección de Estudios $N^{o}$ 63. Servicio de Publicaciones de la Universidad Autónoma de Madrid.

PEDRAZA, J., R. M. CARRASCO, J. F. MARTÍNDUQUE y M. A. SANZ SANTOS. 2004. El Macizo de Peñalara (Sistema Central Español). Morfoestructura y modelado. Bol. R. Soc. Esp. Hist. Nat. (Sec.Geol.), 99(1-4): 185-196.

PEÑALBA, M. C., M. ARNOLD, J. GUIOT, J. C. DUPLESSY and J. L. DE BEAULIEU. 1997. Termination of the Last Glaciation in the Iberian Peninsula inferred from the pollen sequence of Quintanar de la Sierra. Quaternary Research, 48(2): 205-214.

PICTET, A. E. 1865. Synopsis des Névroptéres d'Espagne. Genéve. H. Georg, Libraire, Corraterie. $123 \mathrm{pp}$.

POFF, N. L., M. M. BRINSON \& J. W. DAY. 2002. Aquatic ecosystems and global climate change. Potential impacts o inland freshwater and coastal wetlands ecosystems in the United States. Pew Center on Global Climate Change. Arlington. 44 pp.

PSENNER, R. 1988. Alkalinity generation in a softwater lake: Watershed and in-lake processes. Limnol. Oceanogr., 33: 1463-1475.

PSENNER, R. y J. CATALAN. 1994. Chemical composition of lakes in crystalline basins: a combination of atmospheric deposition, geologic background, biological activity and human action. In: Limnology now: a paradigm of planetary problems. R. Margalef (ed.): 255-314. Elsevier Science B.V.

PSENNER, R. 1999. Living in a dusty world: airborne dust as a key factor for alpine lakes. Water Air Soil Pollut., 112: 217-227.

RICHARDSON, J. R. \& C. W. BERISH. 2003. Data and information issues in modeling for resource management decision making: communication is the key. In: Ecological Modeling for Resource management. V.H. Daler (ed.). 328 pp. SpringerVerlag. New York.

ROBLES, S., J. M. RODRÍGUEZ, I. GRANADOS \& M. C. GUERRERO. 2000. Sulfite-reducing clos- 
tridia in the sediment of a high mountain lake (Laguna Grande, Gredos, Spain) as indicators of faecal pollution. Internatl. Microbiol., 3: 187-191.

ROBLES, S. y J. J. ALDASORO. 2001. Zooplancton. En: Las lagunas del Parque Regional de la Sierra de Gredos. M. Toro \& I. Granados (eds.): 105118. Monografías de la Red de Espacios Naturales de Castilla y León. Serie Técnica: Junta de Castilla y León. Valladolid.

ROGORA, M., R. MOSELLO \& A. MARCHETTO. 2004. Long-term trends in the chemistry of atmospheric deposition in Northwestern Italy: the role of increasing Sharan dust deposition. Tellus, 56B: 426-434.

ROSSARO, B. 1982. Chironomidii, 2. Consiglio Nazionale Delle Ricerche AQ/1?171. Guide per il Riconoscimento delle Specie Animali delle Acque Interne Italiane, N. 16.80 pp.

RUIZ-ZAPATA, M. B., M. J. GIL, M. DORADO, A. ANDRADE, T. MARTIN \& A. VALDEOLMILLOS. 1997. Vegetación y paleoambientes en el Sistema Central español. Actas de la IV Reunión del Cuaternario Ibérico. J. Rodríguez Vidal (ed.): 248-260.

SANZ-HERRAIZ, C. 1977. Morfología glaciar en la Sierra de Guadarrama. El modelado de las áreas glaciares y periglaciares (Peñalara-Los Pelados). $V$ Coloquio de Geografía. Granada: 49-55.

SANZ-HERRAIZ, C. 1988. El relieve del Guadarrama Oriental. Consejería de Política Territorial, Comunidad de Madrid. 547 pp.

SANZ-HERRAIZ, C. 1999. Geomorfología glaciar del Parque Natural de Peñalara. Primeros Encuentros Científicos del Parque Natural de Peñalara y del Valle de El Paular. Consejería de medio Ambiente, Comunidad de Madrid: 121-126.

SCOTT, W. B. y E. J. CROSSMAN. 1973. Freshwater fishes of Canada. Fish. Res. Bd. Can. Bull., 184. Ottawa.

SLUSARCZYK, M. 1997. Impact of fish predation on a small-bodied cladoceran: limitation or stimulation?. Hydrobiologia, 342/343: 215-221.

SORIANO, O. 1995. Los quironómidos (Diptera, Chironomidae) de Madrid : efecto de la regulación ejercida por el embalse del Vado (Guadalajara, España) sobre una comunidad de quironómidos. Tesis doctoral, Universidad Complutense de Madrid. $431 \mathrm{pp}$.

SOURNIA, A. 1978. Phytoplankton manual. Monographs on Oceanographic Methodology 6, UNESCO. Paris, France. 337 pp.
STENSON, J. A. 1982. Fish impact on rotifer community structure. Hydrobiologia, 87, 57-64.

TAIT, D. \& B. THALER. 2000. Atmospheric deposition and lake chemistry trends at a high mountain site in the eastern Alps. J. Limnol., 59(1): 61-71.

TORO, M. y C. MONTES. 1993. Bases Limnológicas para la Gestión del Sistema Lagunar del Parque Natural de la Cumbre, Circo y Lagunas de Peñalara. Departamento de Ecología de la Universidad Autónoma de Madrid. Agencia de Medio Ambiente de la Comunidad de Madrid. 216 pp.

TORO, M., R. J. FLOWER, N. ROSE \& A. C. STEVENSON. 1993. The sedimentary record of the recent history in a high mountain lake in Central Spain. Verh. Internat. Verein. Limnol., 25: 11081112.

TORO, M. e I. GRANADOS. 1997. Laguna de Peñalara. Seguimiento Limnológico y Control de las Medidas Adoptadas en la Gestión del Parque Natural. (julio 1995 - diciembre 1996). Consejería de Medio Ambiente y Desarrollo Regional. Comunidad de Madrid. 130 pp.

TORO, M. e I. GRANADOS. 1998. Inventario, Cartografía y Caracterización de las Charcas y Lagunas del Parque Natural de la Cumbre, Circo $y$ Lagunas de Peñalara. Consejería de Medio Ambiente y Desarrollo Regional. Comunidad de Madrid. $100 \mathrm{pp}$.

TORO, M. e I. GRANADOS. 1999. Laguna de Peñalara. Seguimiento Limnológico y Control de las Medidas Adoptadas en la Gestión del Parque Natural. (Año 1998). Consejería de Medio Ambiente y Desarrollo Regional. Comunidad de Madrid. 48 pp.

TORO, M., I. GRANADOS y L. NAVALÓN. 2000. Las lagunas del macizo de Peñalara (Sierra de Guadarrama, Madrid). En: Conservación de Lagos y Humedales de Alta Montaña de la Península Ibérica. I. Granados y M. Toro (eds.): 217-228. Colección de Estudios $N^{\circ}$ 63. Servicio de Publicaciones de la Universidad Autónoma de Madrid.

TORO, M. e I. GRANADOS (eds.). 2001. Las lagunas del Parque Regional de la Sierra de Gredos. Monografías de la Red de Espacios Naturales de Castilla y León. Serie Técnica: Junta de Castilla y León. Valladolid. 242 pp.

TORO, M., \& I. GRANADOS. 2002. Restoration of a small high mountain lake after recent tourist impact: the importance of limnological monitoring and palaeolimnology. Water, Air and Soil Pollution: Focus, 2 (2): 295-310. 
VEGA, J. C., C. DE HOYOS \& J. J. ALDASORO. 1991. Estudio del sistema de lagunas de las Sierras Segundera y Cabrera. Monografias de la Red de Espacios Naturales de Castilla y Leon. Junta de Castilla y Leon. Valladolid. 47 pp.

VESKI, S., K. KOPPEL \& A. POSKA. 2005. Integrated palaeoecological and historical data in the service of fine-resolution land use and ecological change assessment during the last 1000 years in Rõuge, southern Estonia. Journal of Biogeography, 32: 1473-1488.

WALKER, I. 1987. Chironomidae (Diptera) in palaeoecology. Quaternary Science Reviews, 6: 29-40.

WALKER, I., J. P. SMOL, D. R. ENGSROM \& H. J. B. BIRKS. 1991. An assessment of chironomidae as quantitative indicators of past climatic change. Can. J. Fisheries. Aqua. Sci., 48: 975-987.

WATHNE, B. M. y H. H. HANSEN. 1997. MOLAR. Measuring and modelling the dynamic response of remote mountain lake ecosystem to environmental change: A program of Mountain lake Research. MOLAR Project Manual. NIVA-EC Report 096061, Oslo.

WELCH, H. E. \& M. A. BERGMAN. 1985. Water circulation in small arctic lakes in winter. Can. J. Fish. Aquat. Sci., 43: 506-520.

WHITESIDE, M. C. 1983. The mythical concept of eutrophication. Hydrobiologia, 103: 107-111.

WILLIAMS, M. W., BROWN, A. D. \& MELACK, J. M. 2005. Geochemical and hydrologic controls on the composition of surface water in a high-elevation basin, Sierra Nevada, California. Limnology and Oceanography, 38 (4): 775-797.

WÖGRATH, S. \& R. PSENNER. 1995. Seasonal, annual and long-term variability in the water chemistry of a remote high mountain lake: acid rain versus natural changes. Water, Air and Soil Pollution, 85: 359-364. 